\title{
Optical Continuum and Emission\#Line Variability of the Seyfert 1 Galaxy Markarian 509
}

\section{Citation}

Carone, T. E., B. M. Peterson, J. Bechtold, R. Bertram, K. Bischoff, M. Dietrich, A. V. Filppenko, et al. 1996. "Optical Continuum and Emission\#Line Variability of the Seyfert 1 Galaxy Markarian 509." The Astrophysical Journal 471 (2) (November 10): 737-747. doi:10.1086/178002.

\section{Published Version}

doi:10.1086/178002

\section{Permanent link}

http://nrs.harvard.edu/urn-3:HUL.InstRepos:30212161

\section{Terms of Use}

This article was downloaded from Harvard University's DASH repository, and is made available under the terms and conditions applicable to Other Posted Material, as set forth at http:// nrs.harvard.edu/urn-3:HUL.InstRepos:dash.current.terms-of-use\#LAA

\section{Share Your Story}

The Harvard community has made this article openly available.

Please share how this access benefits you. Submit a story.

\section{Accessibility}




\title{
OPTICAL CONTINUUM AND EMISSION-LINE VARIABILITY OF THE SEYFERT 1 GALAXY MARKARIAN 509
}

T. E. Carone, ${ }^{1,2}$ B. M. Peterson,${ }^{3}$ J. Bechtold,${ }^{1}$ R. Bertram, ${ }^{3,4}$ K. Bischoff,${ }^{5}$ M. Dietrich, ${ }^{6}$ A. V. FilippenKo, ${ }^{7}$ L. C. Ho, ${ }^{7,8}$ J. P. HuChra, ${ }^{8}$ W. KollatsChNY, ${ }^{5}$ K. T. Korista,,${ }^{3,9,10}$ T. Matheson, ${ }^{7}$ R. W. PogGe, ${ }^{3}$ J. C. ShIELds,${ }^{1,7,11,12}$ P. S. Smith, ${ }^{1}$ R. M. WAGNER, ${ }^{3,4}$ AND B. J. WILKES ${ }^{8}$ Received 1996 March 17; accepted 1996 June 10

\begin{abstract}
We report on the results of a 5 year coordinated program of spectroscopic monitoring of the luminous Seyfert 1 galaxy Markarian 509. The $\mathrm{H} \beta$ and $\mathrm{He}$ II $\lambda 4686$ emission lines are found to respond to continuum variations with time lags of $\sim 80$ and $\sim 60$ days, respectively, considerably longer than the emission-line lags measured for other Seyfert galaxies.
\end{abstract}

Subject headings: galaxies: active — galaxies: individual (Markarian 509) — galaxies: Seyfert

\section{INTRODUCTION}

Over the last several years, great progress in probing the central environment of active galactic nuclei (AGNs) has been made by use of "reverberation mapping" techniques (Blandford \& McKee 1982), whereby the geometry and kinematics of the broad-line region (BLR) can be inferred from the detailed response of the broad emission lines to continuum variations (see Peterson 1993, 1994 for recent reviews).

Most of the AGNs that have been monitored closely thus far are nearby Seyfert 1 galaxies that have a known history of continuum and emission-line variability, although higher luminosity AGNs (quasars) are now beginning to receive more attention (e.g., Maoz et al. 1994; Maoz 1994; Erkens et al. 1995). Determination of the emission-line response times (or "lags") for higher luminosity sources is of particular interest because it affords a test of photoionization models of the BLR. For simple photoionization models, the approximate similarity of AGN broad-line spectra implies that the ionization parameter $U$ (i.e., the ratio of ionizing photons to particles at the inward face of a line-emitting cloud) and particle density in the BLR do not vary strongly with luminosity. If the shape of AGN ionizing continua is also independent of luminosity, one is led directly to the simple and testable prediction that the size of the BLR $r$ should scale with luminosity $L$ as

$$
r \propto L^{1 / 2} .
$$

\footnotetext{
${ }^{1}$ Steward Observatory, University of Arizona, Tucson, AZ 85721.

2 Current address: 28740 West Fox River Drive, Cary, IL 60013.

${ }^{3}$ Department of Astronomy, The Ohio State University, 174 West 18 th Avenue, Columbus, $\mathrm{OH} 43210$.

${ }^{4}$ Mailing address: Lowell Observatory, Mars Hill Road, 1400 West, Flagstaff, AZ 86001.

${ }^{5}$ Universitäts-Sternwarte Göttingen, Geismarlandstrasse 11, D-37083 Göttingen, Germany.

${ }^{6}$ Landessternwarte, Königstuhl, D-69117 Heidelberg, Germany. 94720

Department of Astronomy, University of California, Berkeley, CA

${ }^{8}$ Harvard-Smithsonian Center for Astrophysics, 60 Garden Street, Cambridge, MA 02138.

${ }^{9}$ Observatories of the Carnegie Institution of Washington, 813 Santa Barbara Street, Pasadena, CA 91101.

${ }^{10}$ Department of Physics and Astronomy, University of Kentucky, Lexington, KY 40506

11 Hubble Fellow.

12 Present address: Department of Physics and Astronomy, Ohio University, Clippinger Research Labs. 251B, Athens, OH 45701.
}

In this paper, we describe the initial results of a 5 year intensive monitoring program on the luminous Seyfert 1 galaxy Markarian (Mrk) 509. While the apparent magnitude $(B \approx 13.9 \mathrm{mag}$ ) of Mrk 509 is similar to those of other AGNs that have been monitored intensively, it is more distant than the other well monitored sources $(z \approx 0.034)$ and intrinsically more luminous, with an absolute magnitude $M_{B} \approx-21.1+5 \log h$, where $h$ is the Hubble constant in units of $100 \mathrm{~km} \mathrm{~s}^{-1} \mathrm{Mpc}^{-1}$; this is nearly an order of magnitude more luminous than most of the other well studied sources, and only $0.4 \mathrm{mag}$ fainter than the (arbitrary) division in luminosity between Seyfert galaxies and quasars, as defined by Schmidt \& Green (1983), i.e., $M_{B}(\mathrm{QSOs}) \leq-21.5+5 \log h$.

The observations described in $\S 2$ were made whenever Mrk 509 was accessible between 1988 September and 1993 December with a number of different telescopes. Many of these observations were obtained while the observers were also engaged in a coordinated monitoring of the Seyfert 1 galaxy NGC 5548 (Peterson et al. 1991, 1992, 1994; Korista et al. 1995). Because several different instruments were used in these observations, the separate data sets, although internally homogeneous, need to be adjusted to a common scale to correct for differences that we attribute primarily to aperture effects (e.g., see Peterson et al. 1995). The intercalibration process and methods of measurement are described in $\S 3$. The principal results of this variability study are presented in $\S 4$ and discussed briefly in $\S 5$.

\section{OBSERVATIONS}

A complete log of optical spectroscopic observations appears in Table 1. Columns (1) and (2) give the UT date and Julian date, respectively, of each observation. Column (3) indicates the telescope and instrument that was used to obtain each spectrum. The projected spectrograph entrance aperture, in arcseconds, is given in column (4). The first dimension is the slit width in the dispersion direction, and the second dimension is the slit length in the crossdispersion direction; for CCDs, the latter dimension is the "extraction window" used in the reduction to one dimension. The slit position angle is given in column (5), measured eastward from north; the cross-dispersion direction runs north to south for a position angle $0^{\circ}$. An estimate of the seeing, when it was recorded at the telescope, is given in column (6). In the case of the Ohio State spectra (set "A"), 
TABLE 1

Log of SPeCtroscopic ObServations

\begin{tabular}{|c|c|c|c|c|c|c|c|c|}
\hline \multirow[b]{2}{*}{$\begin{array}{l}\text { UT DATE } \\
\text { (1) }\end{array}$} & \multirow[b]{2}{*}{$\begin{array}{c}\text { Julian Date } \\
\text { (2) }\end{array}$} & \multirow[b]{2}{*}{$\begin{array}{l}\text { CoDE } \\
\text { (3) }\end{array}$} & \multicolumn{2}{|c|}{ APERTURE } & \multirow[b]{2}{*}{$\begin{array}{c}\text { SEEING } \\
\text { (arcsecond) } \\
\text { (6) }\end{array}$} & \multirow[b]{2}{*}{$\begin{array}{c}\text { RESOLUTION } \\
\text { (A) } \\
(7)\end{array}$} & \multirow[b]{2}{*}{$\begin{array}{l}\text { RANGE } \\
(\AA) \\
(8)\end{array}$} & \multirow[b]{2}{*}{$\begin{array}{c}\text { IRAF FILE } \\
\text { (9) }\end{array}$} \\
\hline & & & $\begin{array}{c}\text { Size } \\
\text { (arcsecond) } \\
\text { (4) }\end{array}$ & $\begin{array}{c}\text { P.A. } \\
\text { (degree) } \\
\text { (5) }\end{array}$ & & & & \\
\hline $1988 \operatorname{Sep} 11 \ldots \ldots \ldots$ & 2447415 & B & $3.2 \times 6.4$ & 90 & $\ldots$ & 5 & $4550-7000$ & $\mathrm{~m} 57415 \mathrm{~b}$ \\
\hline 1988 Sep $16 \ldots \ldots$. & 2447420 & B & $3.2 \times 6.4$ & 90 & $\ldots$ & 5 & $4550-7000$ & $\mathrm{~m} 57420 \mathrm{~b}$ \\
\hline 1988 Sep $17 \ldots \ldots \ldots$ & 2447421 & B & $3.2 \times 6.4$ & 90 & $\ldots$ & 5 & $4550-7000$ & $\mathrm{~m} 57421 \mathrm{~b}$ \\
\hline 1988 Oct $8 \ldots$ & 2447442 & B & $3.2 \times 6.4$ & 90 & $\ldots$ & 5 & $4550-7000$ & $\mathrm{~m} 57442 \mathrm{~b}$ \\
\hline 1988 Oct 12 .. & 2447446 & B & $3.2 \times 6.4$ & 90 & $\ldots$ & 5 & $4550-7000$ & $\mathrm{~m} 57446 \mathrm{~b}$ \\
\hline 1988 Nov 7. & 2447472 & B & $3.2 \times 6.4$ & 90 & $\ldots$ & 5 & $4550-7000$ & $\mathrm{~m} 57472 \mathrm{~b}$ \\
\hline 1988 Nov $13 \ldots \ldots$ & 2447478 & B & $3.2 \times 6.4$ & 90 & $\ldots$ & 5 & $4550-7000$ & $\mathrm{~m} 57478 \mathrm{~b}$ \\
\hline 1988 Dec $2 \ldots$ & 2447497 & B & $3.2 \times 6.4$ & 90 & $\ldots$ & 5 & $4590-7000$ & $\mathrm{~m} 57497 \mathrm{~b}$ \\
\hline $1988 \operatorname{Dec} 3 \ldots \ldots \ldots$ & 2447498 & B & $3.2 \times 6.4$ & 90 & $\ldots$ & 5 & $4550-7000$ & $\mathrm{~m} 57498 \mathrm{~b}$ \\
\hline 1988 Dec $5 \ldots \ldots \ldots$ & 2447500 & B & $3.2 \times 6.4$ & 90 & $\ldots$ & 5 & $4590-7000$ & $\mathrm{~m} 57500 \mathrm{~b}$ \\
\hline 1988 Dec $6 \ldots \ldots \ldots$ & 2447501 & B & $3.2 \times 6.4$ & 90 & $\ldots$ & 5 & $4590-7000$ & $\mathrm{~m} 57501 \mathrm{~b}$ \\
\hline 1989 May 7 ....... & 2447653 & A & $5.0 \times 7.6$ & 90 & $>5$ & 9 & $4450-5400$ & $\mathrm{~m} 57653 \mathrm{a}$ \\
\hline 1989 May $11 \ldots \ldots$. & 2447657 & A & $5.0 \times 7.6$ & 90 & $>5$ & 9 & $4470-5600$ & $\mathrm{~m} 57657 \mathrm{a}$ \\
\hline 1989 Маy $17 \ldots \ldots$ & 2447663 & $\mathrm{~F}$ & $2.1 \times 7.0$ & 90 & 2.0 & 5 & $4000-5530$ & m57663fa \\
\hline 1989 May $17 \ldots \ldots$. & 2447663 & $\mathrm{~F}$ & $2.1 \times 7.0$ & 90 & 2.0 & 5 & $5640-7150$ & m57663fb \\
\hline 1989 May $18 \ldots \ldots$. & 2447664 & $\mathrm{~F}$ & $2.1 \times 7.0$ & 90 & $1.5-2$ & 5 & $4750-5300$ & m57664fa \\
\hline 1989 May $18 \ldots \ldots$. & 2447664 & $\mathrm{~F}$ & $2.1 \times 7.0$ & 90 & $1.5-2$ & 5 & $6500-6990$ & $\mathrm{~m} 57664 \mathrm{fb}$ \\
\hline 1989 Jun $1 \ldots \ldots \ldots$ & 2447678 & A & $5.0 \times 7.6$ & 90 & $>5$ & 9 & $4450-5400$ & m57678a \\
\hline 1989 Jun $27 \ldots \ldots \ldots$ & 2447704 & $\mathrm{E}$ & $4.5 \times 27.2$ & 90 & $\ldots$ & 14 & $3200-5800$ & m57704ea \\
\hline 1989 Jun $27 .$. & 2447704 & $\mathrm{E}$ & $4.5 \times 27.2$ & 90 & $\ldots$ & 4 & $4430-5150$ & $\mathrm{~m} 57704 \mathrm{eb}$ \\
\hline 1989 Jun $27 . \ldots \ldots$. & 2447704 & $\mathrm{E}$ & $4.5 \times 27.2$ & 90 & $\ldots$ & 14 & $5680-8270$ & $\mathrm{~m} 57704 \mathrm{ec}$ \\
\hline 1989 Jul $10 \ldots \ldots \ldots$ & 2447717 & B & $3.2 \times 6.4$ & 90 & $\ldots$ & 5 & $4550-7000$ & m57717b \\
\hline 1989 Aug 29. & 2447767 & $\mathrm{E}$ & $4.5 \times 27.2$ & 90 & $\ldots$ & 14 & $3300-5900$ & m57767ea \\
\hline 1989 Aug $29 \ldots \ldots$ & 2447767 & $\mathrm{E}$ & $4.5 \times 27.2$ & 90 & $\ldots$ & 4 & $4440-5180$ & $\mathrm{~m} 57767 \mathrm{eb}$ \\
\hline 1989 Aug $29 \ldots \ldots$ & 2447767 & $\mathrm{E}$ & $4.5 \times 27.2$ & 90 & $\ldots$ & 14 & $5720-8600$ & $\mathrm{~m} 57704 \mathrm{ec}$ \\
\hline 1989 Sep $8 \ldots \ldots \ldots$ & 2447777 & B & $3.2 \times 6.4$ & 90 & $\ldots$ & 5 & $4550-7000$ & m57777b \\
\hline 1989 Sep $9 \ldots \ldots \ldots$ & 2447778 & $\mathrm{E}$ & $4.5 \times 27.2$ & 90 & $\ldots$ & 14 & $3740-5900$ & m57778ea \\
\hline 1989 Sep $9 \ldots \ldots \ldots$ & 2447778 & $\mathrm{E}$ & $4.5 \times 27.2$ & 90 & $\ldots$ & 14 & $5750-8630$ & $\mathrm{~m} 57778 \mathrm{eb}$ \\
\hline 1989 Sep $10 \ldots \ldots$. & 2447779 & $\mathrm{E}$ & $4.5 \times 27.2$ & 90 & $\ldots$ & 14 & $3450-5900$ & m57779ea \\
\hline 1989 Sep $10 \ldots$ & 2447779 & $\mathrm{E}$ & $4.5 \times 27.2$ & 90 & $\ldots$ & 4 & $4440-5230$ & $\mathrm{~m} 57779 \mathrm{eb}$ \\
\hline 1989 Sep $10 \ldots \ldots \ldots$ & 2447779 & $\mathrm{E}$ & $4.5 \times 27.2$ & 90 & $\ldots$ & 14 & $5740-8630$ & $\mathrm{~m} 57779 \mathrm{ec}$ \\
\hline 1989 Sep $14 \ldots \ldots \ldots$ & 2447783 & $\bar{A}$ & $5.0 \times 7.6$ & 90 & 4.0 & 9 & $4570-5670$ & $\mathrm{~m} 57783 \mathrm{a}$ \\
\hline $1989 \operatorname{Sep} 19 .$. & 2447788 & A & $5.0 \times 7.6$ & 90 & 4.6 & 9 & $4580-5720$ & $\mathrm{~m} 57788 \mathrm{a}$ \\
\hline 1989 Sep $29 \ldots \ldots \ldots$ & 2447798 & B & $3.2 \times 6.4$ & 90 & $\ldots$ & 5 & $4550-7000$ & $\mathrm{~m} 57798 \mathrm{~b}$ \\
\hline 1989 Sep $30 \ldots \ldots$ & 2447799 & B & $3.2 \times 6.4$ & 90 & $\ldots$ & 5 & $4550-7000$ & $\mathrm{~m} 57799 \mathrm{~b}$ \\
\hline 1989 Oct $1 \ldots \ldots \ldots$ & 2447800 & B & $3.2 \times 6.4$ & 90 & $\ldots$ & 5 & $4550-7000$ & $\mathrm{~m} 57800 \mathrm{~b}$ \\
\hline 1989 Oct $6 \ldots \ldots \ldots$ & 2447805 & B & $3.2 \times 6.4$ & 90 & $\ldots$ & 5 & $4550-7000$ & $\mathrm{~m} 57805 \mathrm{~b}$ \\
\hline 1989 Oct $17 \ldots \ldots$ & 2447816 & A & $5.0 \times 7.6$ & 90 & 4.6 & 9 & $4510-5640$ & $\mathrm{~m} 57816 \mathrm{a}$ \\
\hline 1989 Oct $24 \ldots \ldots \ldots$ & 2447823 & B & $3.2 \times 6.4$ & 90 & $\ldots$ & 5 & $4550-7000$ & $\mathrm{~m} 57823 \mathrm{~b}$ \\
\hline 1989 Oct $25 \ldots \ldots \ldots$ & 2447824 & B & $3.2 \times 6.4$ & 90 & $\ldots$ & 5 & $4550-7000$ & $\mathrm{~m} 57824 \mathrm{~b}$ \\
\hline 1989 Oct $26 \ldots \ldots$ & 2447826 & $\mathrm{~F}$ & $2.0 \times 7.0$ & 90 & 2.0 & 5 & $4130-7440$ & $\mathrm{~m} 57826 \mathrm{f}$ \\
\hline 1989 Oct $27 \ldots \ldots$ & 2447826 & B & $3.2 \times 6.4$ & 90 & $\ldots$ & 5 & $4550-7000$ & $\mathrm{~m} 57826 \mathrm{~b}$ \\
\hline 1989 Oct $30 \ldots \ldots$ & 2447829 & B & $3.2 \times 6.4$ & 90 & . & 5 & $4550-7000$ & $\mathrm{~m} 57829 \mathrm{~b}$ \\
\hline 1989 Nov 1 ....... & 2447831 & A & $5.0 \times 7.6$ & 90 & 5.0 & 9 & $4550-5630$ & m57831a \\
\hline 1989 Nov $1 \ldots \ldots$. & 2447831 & B & $3.2 \times 6.4$ & 90 & $\ldots$ & 5 & $4550-7000$ & $\mathrm{~m} 57831 \mathrm{~b}$ \\
\hline 1989 Nov 2 ....... & 2447832 & B & $3.2 \times 6.4$ & 90 & $\ldots$ & 5 & $4550-7000$ & $\mathrm{~m} 57832 \mathrm{~b}$ \\
\hline 1989 Nov 3 ....... & 2447833 & B & $3.2 \times 6.4$ & 90 & $\ldots$ & 5 & $4550-7000$ & $\mathrm{~m} 57833 \mathrm{~b}$ \\
\hline 1989 Nov 4 ....... & 2447834 & B & $3.2 \times 6.4$ & 90 & $\ldots$ & 5 & $4550-7000$ & $\mathrm{~m} 57834 \mathrm{~b}$ \\
\hline 1989 Nov 5 ....... & 2447835 & B & $3.2 \times 6.4$ & 90 & $\ldots$ & 5 & $4550-7000$ & $\mathrm{~m} 57835 \mathrm{~b}$ \\
\hline 1989 Nov 7 ....... & 2447837 & A & $5.0 \times 7.6$ & 90 & 4.2 & 9 & $4590-5700$ & m57837a \\
\hline 1989 Nov $16 \ldots \ldots$ & 2447846 & A & $5.0 \times 7.6$ & 90 & 4.1 & 9 & $4570-5710$ & m57846a \\
\hline 1989 Nov $22 \ldots \ldots$ & 2447852 & A & $5.0 \times 7.6$ & 90 & 5.3 & 9 & $4570-5720$ & $\mathrm{~m} 57852 \mathrm{a}$ \\
\hline 1989 Nov $29 \ldots \ldots$ & 2447859 & B & $3.2 \times 6.4$ & 90 & $\ldots$ & 5 & $4550-7000$ & $\mathrm{~m} 57859 \mathrm{~b}$ \\
\hline $1989 \operatorname{Dec} 8 \ldots \ldots \ldots$ & 2447868 & A & $5.0 \times 7.6$ & 90 & 4.5 & 9 & $4590-5730$ & m57868a \\
\hline 1990 May $9 . \ldots \ldots$. & 2448020 & A & $5.0 \times 7.6$ & 90 & 4.4 & 9 & $4520-5690$ & $\mathrm{~m} 58020 \mathrm{a}$ \\
\hline 1990 May $26 \ldots \ldots$. & 2448037 & A & $5.0 \times 7.6$ & 90 & 3.5 & 9 & $4540-5670$ & $\mathrm{~m} 58037 \mathrm{a}$ \\
\hline 1990 Jun $2 \ldots \ldots \ldots$ & 2448044 & A & $5.0 \times 7.6$ & 90 & 5.5 & 9 & $4290-5430$ & $\mathrm{~m} 58044 \mathrm{a}$ \\
\hline 1990 Jun $17 \ldots \ldots .$. & 2448059 & B & $3.2 \times 6.4$ & 90 & $\ldots$ & 5 & $4570-7000$ & $\mathrm{~m} 58059 \mathrm{~b}$ \\
\hline 1990 Jun $18 \ldots \ldots \ldots$ & 2448060 & B & $3.2 \times 6.4$ & 90 & $\ldots$ & 5 & $4600-7000$ & $\mathrm{~m} 58060 \mathrm{~b}$ \\
\hline 1990 Jun $19 \ldots \ldots$ & 2448061 & $\mathrm{~A}$ & $5.0 \times 7.6$ & 90 & 3.6 & 9 & $4520-5660$ & m58061a \\
\hline 1990 Jun $19 . \ldots \ldots$ & 2448061 & B & $3.2 \times 6.4$ & 90 & $\ldots$ & 5 & $4580-7000$ & $\mathrm{~m} 58061 \mathrm{~b}$ \\
\hline 1990 Jun $22 \ldots \ldots \ldots$ & 2448064 & B & $3.2 \times 6.4$ & 90 & $\ldots$ & 5 & $4580-7000$ & $\mathrm{~m} 58064 \mathrm{~b}$ \\
\hline 1990 Jun $23 \ldots \ldots$. & 2448065 & B & $3.2 \times 6.4$ & 90 & $\ldots$ & 5 & $4590-7000$ & $\mathrm{~m} 58065 \mathrm{~b}$ \\
\hline 1990 Jun $26 \ldots \ldots$. & 2448068 & $\mathrm{~A}$ & $5.0 \times 7.6$ & 90 & 4.0 & 9 & $4510-5650$ & $\mathrm{~m} 58068 \mathrm{a}$ \\
\hline $1990 \mathrm{Ju} 15 \ldots \ldots \ldots$ & 2448077 & A & $5.0 \times 7.6$ & 90 & 3.4 & 9 & $4430-5570$ & m58077a \\
\hline 1990 Jul $16 \ldots \ldots \ldots$ & 2448088 & F & $2.0 \times 7.0$ & 90 & $2-3$ & 5 & $4000-7280$ & $\mathrm{~m} 58088 \mathrm{f}$ \\
\hline $1990 \mathrm{Ju} 118 \ldots \ldots \ldots$ & 2448090 & A & $5.0 \times 7.6$ & 90 & 3.6 & 9 & $4470-5610$ & m58090a \\
\hline $1990 \mathrm{Jul} 30 \ldots \ldots \ldots$ & 2448102 & $\mathrm{D}$ & $8.0 \times 8.0$ & 20 & $1-1.5$ & 10 & $3250-9700$ & $\mathrm{~m} 58102 \mathrm{~d}$ \\
\hline 1990 Aug $9 . \ldots \ldots \ldots$ & 2448112 & $\mathrm{~A}$ & $5.0 \times 7.6$ & 90 & 3.4 & 9 & $4530-5670$ & $\mathrm{~m} 58112 \mathrm{a}$ \\
\hline
\end{tabular}


TABLE 1-Continued

\begin{tabular}{|c|c|c|c|c|c|c|c|c|}
\hline \multirow[b]{2}{*}{$\begin{array}{l}\text { UT DATE } \\
(1)\end{array}$} & \multirow[b]{2}{*}{$\begin{array}{c}\text { JuLIAN DATE } \\
\text { (2) }\end{array}$} & \multirow[b]{2}{*}{$\begin{array}{l}\text { CoDE } \\
\text { (3) }\end{array}$} & \multicolumn{2}{|c|}{ APERTURE } & \multirow[b]{2}{*}{$\begin{array}{c}\text { SEEING } \\
\text { (arcsecond) } \\
(6)\end{array}$} & \multirow[b]{2}{*}{$\begin{array}{c}\text { RESOLUTION } \\
(\AA) \\
(7)\end{array}$} & \multirow[b]{2}{*}{$\begin{array}{c}\text { RANGE } \\
(\AA) \\
(8)\end{array}$} & \multirow[b]{2}{*}{$\begin{array}{c}\text { IRAF FILE } \\
\text { (9) }\end{array}$} \\
\hline & & & $\begin{array}{c}\text { Size } \\
\text { (arcsecond) } \\
\text { (4) }\end{array}$ & $\begin{array}{c}\text { P.A. } \\
\text { (degree) } \\
(5)\end{array}$ & & & & \\
\hline 1990 Aug 25 & 2448128 & A & $5.0 \times 7.6$ & 90 & 4.1 & 9 & $4520-5650$ & $\mathrm{~m} 58128 \mathrm{a}$ \\
\hline 1990 Sep $9 .$. & 2448143 & A & $5.0 \times 7.6$ & 90 & 2.3 & 9 & $4530-5670$ & m58143a \\
\hline 1990 Sep $14 .$. & 2448148 & A & $5.0 \times 7.6$ & 90 & 3.0 & 9 & $4540-5680$ & $\mathrm{~m} 58148 \mathrm{a}$ \\
\hline 1990 Sep $15 \ldots \ldots$. & 2448149 & A & $5.0 \times 7.6$ & 90 & 3.8 & 9 & $4600-5690$ & $\mathrm{~m} 58149 \mathrm{a}$ \\
\hline 1990 Sep $17 \ldots \ldots$. & 2448151 & A & $5.0 \times 7.6$ & 90 & 2.7 & 9 & $4530-5670$ & $\mathrm{~m} 58151 \mathrm{a}$ \\
\hline 1990 Sep $17 \ldots \ldots$. & 2448151 & B & $3.2 \times 6.4$ & 90 & $\ldots$ & 5 & $4580-7000$ & $\mathrm{~m} 58151 \mathrm{~b}$ \\
\hline 1990 Sep $26 \ldots \ldots$. & 2448160 & $\mathrm{~A}$ & $5.0 \times 7.6$ & 90 & 1.8 & 9 & $4540-5680$ & m58160a \\
\hline 1990 Sep $27 \ldots \ldots$. & 2448161 & D & $10.0 \times 10.0$ & 20 & 2 & 20 & $3940-9680$ & m58161d \\
\hline 1990 Sep $28 \ldots \ldots \ldots$ & 2448162 & B & $3.2 \times 6.4$ & 90 & $\ldots$ & 5 & $4580-7000$ & $\mathrm{~m} 58162 \mathrm{~b}$ \\
\hline 1990 Oct $11 \ldots \ldots$ & 2448175 & A & $5.0 \times 7.6$ & 90 & $>5$ & 9 & $4520-5660$ & $\mathrm{~m} 58175 \mathrm{a}$ \\
\hline 1990 Oct $15 \ldots \ldots$ & 2448179 & A & $5.0 \times 7.6$ & 90 & 2.4 & 9 & $4540-5680$ & $\mathrm{~m} 58179 \mathrm{a}$ \\
\hline 1990 Oct $15 \ldots \ldots$ & 2448179 & B & $3.2 \times 6.4$ & 90 & $\ldots$ & 5 & $4600-7000$ & $\mathrm{~m} 58179 \mathrm{~b}$ \\
\hline 1990 Oct $20 \ldots \ldots$. & 2448184 & D & $10.0 \times 10.0$ & 10 & $2-3$ & 20 & $3140-9690$ & $\mathrm{~m} 58184 \mathrm{~d}$ \\
\hline 1990 Oct $23 .$. & 2448187 & A & $5.0 \times 7.6$ & 90 & 3.0 & 9 & $4510-5640$ & $\mathrm{~m} 58187 \mathrm{a}$ \\
\hline 1990 Oct $23 \ldots \ldots$. & 2448187 & B & $3.2 \times 6.4$ & 90 & $\ldots$ & 5 & $4600-7000$ & $\mathrm{~m} 58187 \mathrm{~b}$ \\
\hline 1990 Oct $24 \ldots \ldots$. & 2448188 & B & $3.2 \times 6.4$ & 90 & $\ldots$ & 5 & $4600-7000$ & $\mathrm{~m} 58188 \mathrm{~b}$ \\
\hline 1990 Oct $25 .$. & 2448189 & B & $3.2 \times 6.4$ & 90 & $\ldots$ & 5 & $4600-7000$ & $\mathrm{~m} 58189 \mathrm{~b}$ \\
\hline 1990 Oct $29 .$. & 2448193 & A & $5.0 \times 7.6$ & 90 & 4.8 & 9 & $4520-5650$ & $\mathrm{~m} 58193 \mathrm{a}$ \\
\hline 1990 Nov 5 ....... & 2448200 & A & $5.0 \times 7.6$ & 90 & 4.8 & 9 & $4530-5670$ & $\mathrm{~m} 58200 \mathrm{a}$ \\
\hline 1990 Nov 11. & 2448206 & $\mathrm{D}$ & $10.0 \times 10.0$ & 37 & $1.5-2$ & 20 & $3350-9780$ & m58206d \\
\hline 1990 Nov $12 \ldots .$. & 2448207 & A & $5.0 \times 7.6$ & 90 & 3.4 & 9 & $4530-5670$ & $\mathrm{~m} 58207 \mathrm{a}$ \\
\hline 1990 Nov 25 ...... & 2448220 & A & $5.0 \times 7.6$ & 90 & 4.0 & 9 & $4540-5670$ & $\mathrm{~m} 58220 \mathrm{a}$ \\
\hline 1990 Nov 28 ...... & 2448223 & $\mathrm{C}$ & $8.0 \times 9.0$ & 43 & 3 & 9 & $3480-9980$ & $\mathrm{~m} 58223 \mathrm{c}$ \\
\hline 1990 Dec $5 \ldots \ldots \ldots$ & 2448230 & A & $5.0 \times 7.6$ & 90 & 4.4 & 9 & $4550-5670$ & $\mathrm{~m} 58230 \mathrm{a}$ \\
\hline 1990 Dec $11 \ldots \ldots$ & 2448236 & A & $5.0 \times 7.6$ & 90 & 3.0 & 9 & $4530-5670$ & $\mathrm{~m} 58236 \mathrm{a}$ \\
\hline 1991 Jun $14 \ldots \ldots$. & 2448421 & A & $5.0 \times 7.6$ & 90 & 4.2 & 9 & $4470-5600$ & $\mathrm{~m} 58421 \mathrm{a}$ \\
\hline 1991 Jun $24 \ldots \ldots$. & 2448431 & A & $5.0 \times 7.6$ & 90 & 4.7 & 9 & $4530-5660$ & $\mathrm{~m} 58431 \mathrm{a}$ \\
\hline 1991 Jul 19... & 2448456 & A & $5.0 \times 7.6$ & 90 & 3.2 & 9 & $4520-5650$ & $\mathrm{~m} 58456 \mathrm{a}$ \\
\hline 1991 Jul $23 \ldots \ldots \ldots$ & 2448460 & A & $5.0 \times 7.6$ & 90 & 2.8 & 9 & $4520-5650$ & $\mathrm{~m} 58460 \mathrm{a}$ \\
\hline 1991 Aug $4 \ldots . . .$. & 2448472 & $\mathrm{D}$ & $4.0 \times 10.0$ & 20 & 1.5 & 20 & $3200-9800$ & $\mathrm{~m} 58472 \mathrm{~d}$ \\
\hline 1991 Aug 19 ..... & 2448487 & D & $4.0 \times 10.0$ & 13 & 1 & 20 & $3250-9800$ & $\mathrm{~m} 58487 \mathrm{~d}$ \\
\hline 1991 Sep $13 \ldots \ldots$. & 2448512 & A & $5.0 \times 7.6$ & 90 & 2.8 & 9 & $4560-5650$ & $\mathrm{~m} 58512 \mathrm{a}$ \\
\hline 1991 Sep $14 \ldots \ldots$. & 2448513 & A & $5.0 \times 7.6$ & 90 & 4.0 & 9 & $4550-5640$ & $\mathrm{~m} 58513 \mathrm{a}$ \\
\hline 1991 Sep $15 \ldots \ldots$. & 2448514 & A & $5.0 \times 7.6$ & 90 & 4.1 & 9 & $4560-5650$ & $\mathrm{~m} 58514 \mathrm{a}$ \\
\hline 1991 Sep $17 \ldots \ldots$ & 2448516 & A & $5.0 \times 7.6$ & 90 & 4.1 & 9 & $4560-5650$ & $\mathrm{~m} 58516 \mathrm{a}$ \\
\hline 1991 Sep $21 \ldots \ldots$ & 2448520 & A & $5.0 \times 7.6$ & 90 & 3.1 & 9 & $4540-5630$ & $\mathrm{~m} 58512 \mathrm{a}$ \\
\hline 1991 Oct $5 \ldots \ldots \ldots$ & 2448534 & A & $5.0 \times 7.6$ & 90 & 2.8 & 9 & $4540-5630$ & $\mathrm{~m} 58534 \mathrm{a}$ \\
\hline 1992 Apr 21 ..... & 2448733 & A & $5.0 \times 7.6$ & 90 & 3.9 & 9 & $4530-5680$ & $\mathrm{~m} 58733 \mathrm{a}$ \\
\hline 1992 Jun $7 \ldots$ & 2448780 & A & $5.0 \times 7.6$ & 90 & 3.9 & 9 & $4540-5700$ & $\mathrm{~m} 58780 \mathrm{a}$ \\
\hline 1992 Jun $16 \ldots \ldots$. & 2448789 & A & $5.0 \times 7.6$ & 90 & 3.7 & 9 & $4550-5710$ & $\mathrm{~m} 58789 \mathrm{a}$ \\
\hline 1992 Jun $23 \ldots \ldots$. & 2448796 & A & $5.0 \times 7.6$ & 90 & 3.3 & 9 & $4490-5650$ & m58796a \\
\hline 1992 Jun $25 \ldots \ldots$. & 2448798 & D & $4.0 \times 10.0$ & 61 & 2.5 & 10 & $3300-8200$ & m58798d \\
\hline 1992 Jul 7 ........ & 2448810 & A & $5.0 \times 7.6$ & 90 & 1.4 & 9 & $4540-5700$ & $\mathrm{~m} 58810 \mathrm{a}$ \\
\hline 1992 Jul $14 \ldots \ldots \ldots$ & 2448817 & A & $5.0 \times 7.6$ & 90 & 3.2 & 9 & $4550-5720$ & $\mathrm{~m} 58817 \mathrm{a}$ \\
\hline 1992 Jul $22 \ldots \ldots \ldots$ & 2448825 & A & $5.0 \times 7.6$ & 90 & 2.8 & 9 & $4540-5700$ & $\mathrm{~m} 58825 \mathrm{a}$ \\
\hline 1992 Aug $5 \ldots \ldots \ldots$ & 2448839 & A & $5.0 \times 7.6$ & 90 & $>5$ & 9 & $4570-5730$ & $\mathrm{~m} 58839 \mathrm{a}$ \\
\hline 1992 Aug 14 ..... & 2448848 & A & $5.0 \times 7.6$ & 90 & 2.2 & 9 & $4510-5670$ & $\mathrm{~m} 58848 \mathrm{a}$ \\
\hline 1992 Aug 28 ...... & 2448862 & A & $5.0 \times 7.6$ & 90 & 2.6 & 9 & $4560-5710$ & $\mathrm{~m} 58862 \mathrm{a}$ \\
\hline 1992 Sep 4 ....... & 2448869 & A & $5.0 \times 7.6$ & 90 & 2.7 & 9 & $4530-5680$ & $\mathrm{~m} 58869 \mathrm{a}$ \\
\hline 1992 Sep $11 \ldots \ldots$ & 2448876 & A & $5.0 \times 7.6$ & 90 & 2.4 & 9 & $4570-5720$ & m58876a \\
\hline 1992 Sep $18 \ldots \ldots$. & 2448883 & A & $5.0 \times 7.6$ & 90 & 2.4 & 9 & $4540-5700$ & $\mathrm{~m} 58883 \mathrm{a}$ \\
\hline 1992 Sep $24 \ldots \ldots$. & 2448889 & A & $5.0 \times 7.6$ & 90 & 2.7 & 9 & $4500-5660$ & $\mathrm{~m} 58889 \mathrm{a}$ \\
\hline 1992 Oct $3 \ldots \ldots \ldots$ & 2448898 & A & $5.0 \times 7.6$ & 90 & 2.9 & 9 & $4510-5670$ & $\mathrm{~m} 58898 \mathrm{a}$ \\
\hline 1992 Oct $10 \ldots \ldots$ & 2448904 & A & $5.0 \times 7.6$ & 90 & 3.1 & 9 & $4560-5680$ & $\mathrm{~m} 58904 \mathrm{a}$ \\
\hline 1992 Oct $16 \ldots \ldots$ & 2448911 & A & $5.0 \times 7.6$ & 90 & 3.1 & 9 & $4520-5680$ & m58911a \\
\hline 1992 Oct $23 \ldots \ldots \ldots$ & 2448918 & A & $5.0 \times 7.6$ & 90 & 2.4 & 9 & $4590-5750$ & m58918a \\
\hline 1992 Nov $3 . . . \ldots$ & 2448929 & A & $5.0 \times 7.6$ & 90 & 3.5 & 9 & $4500-5670$ & $\mathrm{~m} 58929 \mathrm{a}$ \\
\hline 1992 Nov 27 ...... & 2448954 & A & $5.0 \times 7.6$ & 90 & 2.5 & 9 & $4550-5710$ & $\mathrm{~m} 58954 \mathrm{a}$ \\
\hline 1993 Apr $2 \ldots \ldots \ldots$ & 2449079 & A & $5.0 \times 7.6$ & 90 & 3.2 & 9 & $4500-5670$ & $\mathrm{~m} 59079 \mathrm{a}$ \\
\hline 1993 Apr $22 \ldots \ldots$ & 2449099 & A & $5.0 \times 7.6$ & 90 & 3.6 & 9 & $4570-5720$ & m59099a \\
\hline 1993 Apr $30 \ldots \ldots$ & 2449107 & A & $5.0 \times 7.6$ & 90 & 4.0 & 9 & $4510-5660$ & $\mathrm{~m} 59107 \mathrm{a}$ \\
\hline 1993 May $7 \ldots \ldots$. & 2449114 & A & $5.0 \times 7.6$ & 90 & 3.5 & 9 & $4470-5630$ & $\mathrm{~m} 59114 \mathrm{a}$ \\
\hline 1993 May $21 \ldots .$. & 2449128 & A & $5.0 \times 7.6$ & 90 & 3.4 & 9 & $4530-5660$ & $\mathrm{~m} 59128 \mathrm{a}$ \\
\hline 1993 May $28 \ldots . .$. & 2449135 & A & $5.0 \times 7.6$ & 90 & 3.5 & 9 & $4510-5660$ & $\mathrm{~m} 59135 \mathrm{a}$ \\
\hline 1993 Jun 4 ....... & 2449142 & A & $5.0 \times 7.6$ & 90 & 3.2 & 9 & $4500-5650$ & $\mathrm{~m} 59142 \mathrm{a}$ \\
\hline 1993 Jun $11 \ldots \ldots$. & 2449149 & A & $5.0 \times 7.6$ & 90 & 4.0 & 9 & $4500-5660$ & $\mathrm{~m} 59149 \mathrm{a}$ \\
\hline 1993 Jun $18 \ldots \ldots$. & 2449156 & A & $5.0 \times 7.6$ & 90 & 3.6 & 9 & $4530-5690$ & m59156a \\
\hline 1993 Jun $25 \ldots \ldots \ldots$ & 2449163 & A & $5.0 \times 7.6$ & 90 & 3.0 & 9 & $4530-5680$ & m59163a \\
\hline 1993 Jul 1 ....... & 2449169 & A & $5.0 \times 7.6$ & 90 & 2.6 & 9 & $4530-5680$ & $\mathrm{~m} 59169 \mathrm{a}$ \\
\hline 1993 Jul 8 ........ & 2449176 & A & $5.0 \times 7.6$ & 90 & 3.1 & 9 & $4530-5690$ & m59176a \\
\hline 1993 Jul $15 \ldots \ldots \ldots$ & 2449183 & A & $5.0 \times 7.6$ & 90 & 2.6 & 9 & $4540-5700$ & $\mathrm{~m} 59183 \mathrm{a}$ \\
\hline
\end{tabular}


TABLE 1-Continued

\begin{tabular}{|c|c|c|c|c|c|c|c|c|}
\hline \multirow[b]{2}{*}{$\begin{array}{l}\text { UT DATE } \\
(1)\end{array}$} & \multirow[b]{2}{*}{$\begin{array}{c}\text { JULIAN DATE } \\
\text { (2) }\end{array}$} & \multirow[b]{2}{*}{$\begin{array}{c}\text { CODE } \\
(3)\end{array}$} & \multicolumn{2}{|c|}{ APERTURE } & \multirow[b]{2}{*}{$\begin{array}{c}\text { SEEING } \\
\text { (arcsecond) } \\
(6)\end{array}$} & \multirow[b]{2}{*}{ 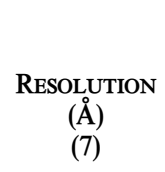 } & \multirow[b]{2}{*}{$\begin{array}{c}\text { RANGE } \\
(\AA) \\
(8)\end{array}$} & \multirow[b]{2}{*}{$\begin{array}{c}\text { IRAF FILE } \\
\text { (9) }\end{array}$} \\
\hline & & & $\begin{array}{c}\text { Size } \\
\text { (arcsecond) } \\
(4)\end{array}$ & $\begin{array}{c}\text { P.A. } \\
\text { (degree) } \\
(5)\end{array}$ & & & & \\
\hline 1993 Jul $22 \ldots \ldots$. & 2449190 & A & $5.0 \times 7.6$ & 90 & 2.4 & 9 & $4560-5720$ & m59190a \\
\hline 1993 Jul 29 ....... & 2449197 & A & $5.0 \times 7.6$ & 90 & 3.8 & 9 & $4530-5690$ & $\mathrm{~m} 59197 \mathrm{a}$ \\
\hline 1993 Aug $6 \ldots \ldots$ & 2449205 & A & $5.0 \times 7.6$ & 90 & 3.0 & 9 & $4540-5700$ & $\mathrm{~m} 59205 \mathrm{a}$ \\
\hline 1993 Aug $12 \ldots \ldots$ & 2449211 & A & $5.0 \times 7.6$ & 90 & 2.9 & 9 & $4520-5680$ & m59211a \\
\hline 1993 Sep $3 \ldots \ldots \ldots$ & 2449233 & A & $5.0 \times 7.6$ & 90 & 2.2 & 9 & $4520-5690$ & m59233a \\
\hline 1993 Sep $10 \ldots \ldots$ & 2449240 & A & $5.0 \times 7.6$ & 90 & 2.0 & 9 & $4530-5690$ & m59240a \\
\hline 1993 Sep $15 \ldots \ldots$ & 2449245 & A & $5.0 \times 7.6$ & 90 & 3.1 & 9 & $4530-5690$ & m59245a \\
\hline 1993 Sep $16 \ldots \ldots$ & 2449246 & A & $5.0 \times 7.6$ & 90 & 2.3 & 9 & $4530-5690$ & m59246a \\
\hline 1993 Sep $23 \ldots \ldots$ & 2449253 & A & $5.0 \times 7.6$ & 90 & 2.6 & 9 & $4520-5670$ & $\mathrm{~m} 59253 \mathrm{a}$ \\
\hline 1993 Sep $30 \ldots \ldots$ & 2449260 & A & $5.0 \times 7.6$ & 90 & 2.8 & 9 & $4520-5670$ & $\mathrm{~m} 59260 \mathrm{a}$ \\
\hline 1993 Oct $8 \ldots \ldots \ldots$ & 2449268 & A & $5.0 \times 7.6$ & 90 & 2.5 & 9 & $4520-5670$ & m59268a \\
\hline 1993 Oct $15 \ldots \ldots$ & 2449275 & A & $5.0 \times 7.6$ & 90 & 2.2 & 9 & $4540-5690$ & $\mathrm{~m} 59275 \mathrm{a}$ \\
\hline 1993 Oct $22 \ldots \ldots$ & 2449282 & A & $5.0 \times 7.6$ & 90 & 2.9 & 9 & $4520-5670$ & m59282a \\
\hline 1993 Nov $5 \ldots \ldots$ & 2449296 & A & $5.0 \times 7.6$ & 90 & 2.4 & 9 & $4530-5690$ & m59296a \\
\hline 1993 Nov $18 \ldots \ldots$ & 2449309 & A & $5.0 \times 7.6$ & 90 & 2.9 & 9 & $4560-5710$ & m59309a \\
\hline 1993 Nov $25 \ldots \ldots$ & 2449316 & A & $5.0 \times 7.6$ & 90 & 4.1 & 9 & $4540-5680$ & m59316a \\
\hline 1993 Dec $2 \ldots \ldots$. & 2449323 & A & $5.0 \times 7.6$ & 90 & 3.2 & 9 & $4540-5700$ & m59323a \\
\hline
\end{tabular}

Note.-Codes for data origin: A, $1.8 \mathrm{~m}$ Perkins Telescope + Ohio State CCD Spectrograph; B, $1.6 \mathrm{~m}$ Mount Hopkins Telescope + Reticon scanner; C, $5.0 \mathrm{~m}$ Hale Telescope +Double Spectrograph; D, $3.0 \mathrm{~m}$ Shane Telescope + UV Schmidt Spectrograph; E, $2.3 \mathrm{~m}$ Steward Observatory Telescope + CCD Spectrograph; F, $2.2 \mathrm{~m}$ Calar Alto Telescope + CCD Spectrograph.

the value given for the seeing is the FWHM of the broad $\mathrm{H} \beta$ profile in the cross-dispersion direction; since the BLR is spatially unresolved, the cross-dispersion width is determined by the point-spread function and guiding errors. The rather large values reported here are due primarily to the large zenith distances at which most of the observations were made, and the marked improvement in the mean values in late 1990 is attributable to implementation of an autoguiding system at the telescope (see Peterson et al. 1995 for a more complete description). The nominal spectral resolution and approximate spectral range covered by the data are given in columns (7) and (8), respectively. Finally,

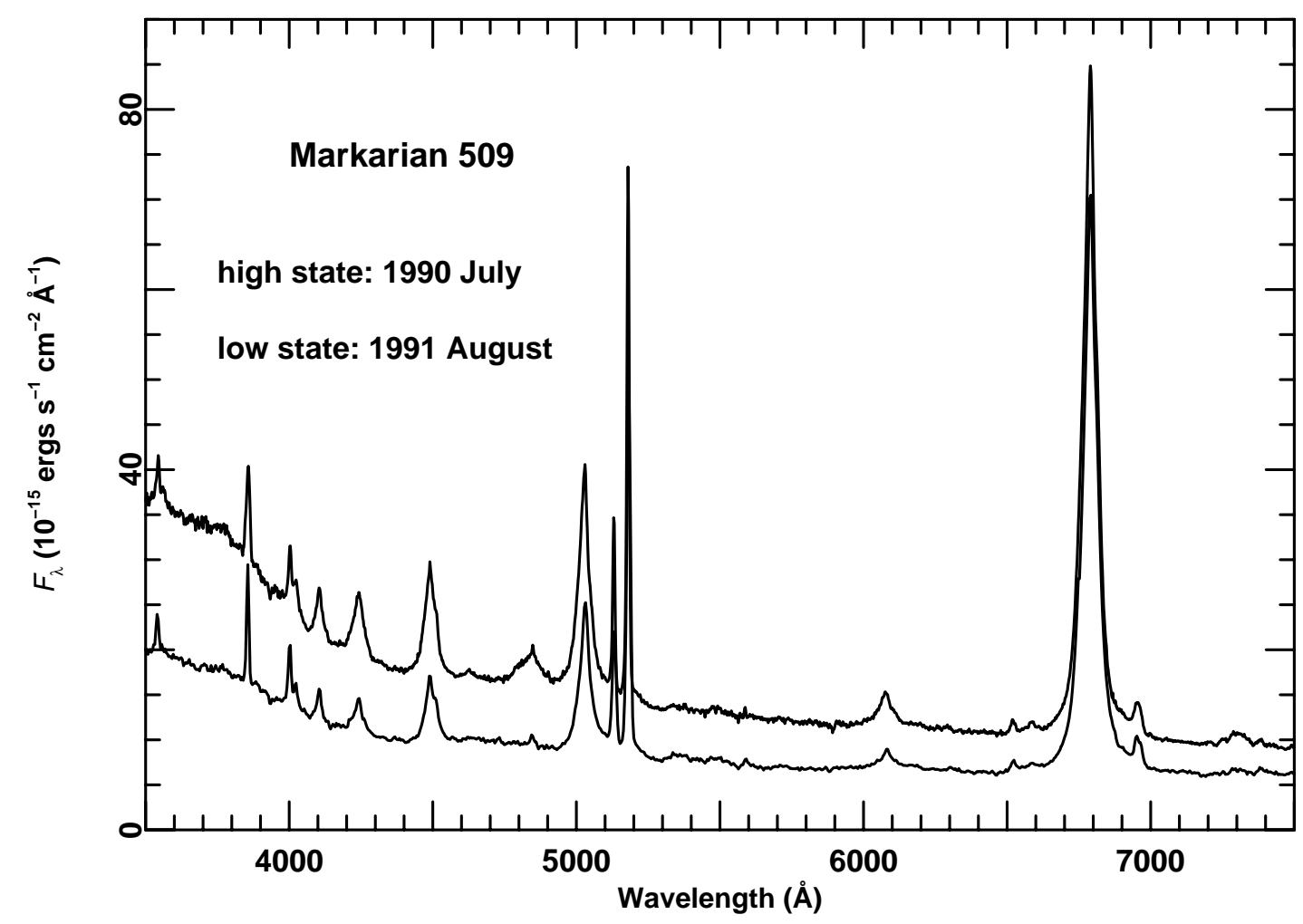

Fig. 1.-Two optical spectra, both obtained with the Lick $3 \mathrm{~m}$ Shane telescope, showing high and low states of Mrk 509. The upper spectrum was obtained on JD 2,448,102 (1990 July 30). The lower spectrum was obtained almost exactly 1 year later on JD 2,448,472 (1991 August 4). Fluxes are in units of $10^{-15} \mathrm{ergs} \mathrm{s}^{-1} \mathrm{~cm}^{-2} \AA^{-1}$ and are shown in the observed frame. The dramatic variation in the strength of He II $\lambda 4686$ (just shortward of $5000 \AA$ in the observed frame) is apparent. 
to aid future investigators who will make use of these data, column (9) gives a unique identifier by which the spectrum is known to the IRAF reduction system, and which is contained in the FITS file header. The file naming convention is the same as used in our other papers (e.g., Peterson et al. 1991, 1992, 1994; Dietrich et al. 1993; Korista et al. 1995): the first two characters (" $\mathrm{m} 5$ ") identify the galaxy as Mrk 509 , and the next four characters (e.g., " 7415 ") contain the four least significant figures in the Julian date, as in column (2). The next character gives the origin of the data, as in column (3), and when necessary, an additional arbitrary character is added to eliminate any remaining ambiguity.

In Figure 1, two sample spectra of Mrk 509 that cover nearly the entire optical spectrum are shown. These spectra were taken at representative high and low flux states, and span the range of activity observed during this 5 year program.

\section{ANALYSIS OF THE DATA}

In this contribution, we will restrict our attention to measuring the variations of the optical continuum at $\sim 5110 \AA$ and the broad $\mathrm{H} \beta$ and $\mathrm{He}$ II $\lambda 4686$ emission lines.

\subsection{Calibration of the Spectra}

Flux calibration of the spectra is accomplished by assuming that the narrow emission lines in the spectra do not vary on the timescales of interest in this experiment. Since these lines arise in a spatially extended $(r \gtrsim 100 \mathrm{pc})$ low-density $\left(n_{e} \approx 10^{3} \mathrm{~cm}^{-3}\right)$ region, the long light-travel time and recombination time will damp out any variations on timescales as short as a few years. We can therefore measure the flux in the strong narrow lines in each spectrum and multiply each spectrum by a suitable constant that will give the correct integrated flux in the narrow lines. We use the differencing method of van Groningen \& Wanders (1992) to obtain the correct multiplicative scaling factor for each spectrum. In this method, one high-quality spectrum is adopted as a reference spectrum (in this case spectrum m58862a). All other spectra are calibrated relative to it by minimizing the residuals of the [O III] $\lambda \lambda 4959,5007$ lines in the difference spectrum produced by subtracting the reference spectrum from a modified version of the spectrum. The narrow-line residuals are minimized in a least-squares fashion by adjusting the multiplicative constant (to adjust the flux scale), the wavelength scale (to account for slight linear wavelength shifts relative to the reference spectrum), and a Gaussian smoothing parameter (which smooths the higher resolution of the two spectra in order to account for slight differences in spectral resolution). By comparing the differences in the optical continuum and emission-line fluxes between closely spaced observations, we estimate that this procedure results in relative errors at the $2 \%-3 \%$ level. With the exception of a few outliers that are the result of observations made under very poor observing conditions, the flux scaling factors are found to be symmetrically distributed about the mean [O III] flux, with a standard deviation of order $15 \%$ or so, which reflects the typical accuracy that can be achieved by using standard spectrophotometric flux-calibration techniques.

Absolute calibration of the spectra is accomplished by determining the absolute [O III] $\lambda 5007$ flux, which is measured from high-quality spectra obtained under photometric conditions through large spectrograph entrance apertures. The absolute [O III] $\lambda 5007$ fluxes measured from suitable spectra are given in Table 2, and we adopt as our standard the mean of these measurements, $F([\mathrm{O} \mathrm{III}]$ 25007) $=6.79 \times 10^{-13} \mathrm{ergs} \mathrm{s}^{-1} \mathrm{~cm}^{-2}$, as measured in the observed frame.

\subsection{Spectral Measurements}

Continuum and emission-line measurements of the calibrated spectra were made in the following way: the continuum flux was measured at the local minimum in the spectrum immediately longward of $\mathrm{H} \beta$ by averaging the flux between 5280 and $5300 \AA$ in the observed frame (i.e., at $\sim 5110 \AA$ in the rest frame of Mrk 509). To measure the $\mathrm{H} \beta$ feature, we define a pseudocontinuum by linear interpolation between the fluxes at 4925 and $5280 \AA$ and then integrating the flux above this line between 4930 and $5106 \AA$ (all wavelengths are given in the observed frame). The optical Fe II blends longward and shortward of $\mathrm{H} \beta$ are relatively weak in Mrk 509, which also enables us to measure the He II $\lambda 4686$ flux in a straightforward manner. In this case, we define the pseudocontinuum points at 4750 and $4900 \AA$ and integrate all the flux above this continuum. It was not possible to measure the He II $\lambda 4686$ feature in those spectra that do not extend to the short wavelength limit of the line integration, which is why there are fewer $\mathrm{He}$ II $\lambda 4686$ measurements than continuum and $\mathrm{H} \beta$ measurements. The measurements made from the calibrated spectra are given in Table 3, grouped by common origin as designated by the codes in Table 1 . Partial blending of the $\mathrm{H} \beta$ and $\mathrm{He}$ II $\lambda 4686$ features is apparent in the brighter states. In principle, our method of setting the pseudocontinuum will thus slightly underestimate the fluxes in both lines. However, the restricted wavelength range of much of the data precludes using a continuum based on more widely separated points. Moreover, the time series analysis that is the most important goal of this investigation is most sensitive to changes in the first and second derivatives of the light curves which are hardly affected at all by precisely how the lines are measured.

\subsection{Intercalibration of the Data}

The individual data sets in Table 3 show similar patterns of variability in both the continuum and the emission lines. However, the light curves produced from the individual sets are slightly offset in flux from one another, and this is attrib-

TABLE 2

Absolute Calibration

\begin{tabular}{|c|c|}
\hline$F\left(\left[\begin{array}{ll}{[\mathrm{III}]} & \lambda 5007)^{\mathrm{a}} \\
(1) & \end{array}\right.\right.$ & $\begin{array}{l}\text { File Name } \\
\text { (2) }\end{array}$ \\
\hline 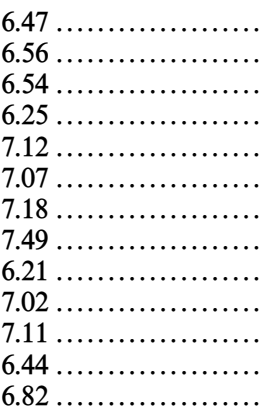 & $\begin{array}{l}\mathrm{m} 57704 \mathrm{ea} \\
\mathrm{m} 57778 \mathrm{ea} \\
\mathrm{m} 57779 \mathrm{ea} \\
\mathrm{m} 57779 \mathrm{eb} \\
\mathrm{m} 57837 \mathrm{a} \\
\mathrm{m} 57852 \mathrm{a} \\
\mathrm{m} 58090 \mathrm{a} \\
\mathrm{m} 58102 \mathrm{~d} \\
\mathrm{~m} 58161 \mathrm{~d} \\
\mathrm{~m} 58187 \mathrm{a} \\
\mathrm{m} 58223 \mathrm{c} \\
\mathrm{m} 58516 \mathrm{a} \\
\mathrm{m} 58862 \mathrm{a}\end{array}$ \\
\hline $6.79 \pm 0.40$. & Mean value \\
\hline
\end{tabular}

${ }^{\mathrm{a}}$ In units of $10^{-13} \mathrm{ergs} \mathrm{cm}^{-2} \mathrm{~s}^{-1}$. 
TABLE 3

MEASUREMENTS OF SPECTRA

\begin{tabular}{|c|c|c|c|c|}
\hline $\begin{array}{c}\text { Julian Date } \\
\text { (1) }\end{array}$ & $F_{\lambda}(5110 \AA)^{\mathrm{a}}$ & $\begin{array}{c}F(\mathrm{H} \beta)^{\mathrm{b}} \\
(3)\end{array}$ & $\begin{array}{c}F(\mathrm{He} \mathrm{II})^{\mathrm{b}} \\
\text { (4) }\end{array}$ & $\begin{array}{c}\text { IRAF File } \\
(5)\end{array}$ \\
\hline \multicolumn{5}{|c|}{ A. Ohio State CCD } \\
\hline $2447653 \ldots \ldots$ & 11.59 & 12.63 & 2.16 & $\mathrm{~m} 57653 \mathrm{a}$ \\
\hline $2447657 \ldots \ldots$ & 11.86 & 12.61 & 1.80 & $\mathrm{~m} 57657 \mathrm{a}$ \\
\hline $2447678 \ldots \ldots$ & 11.23 & 12.34 & 2.32 & $\mathrm{~m} 57678 \mathrm{a}$ \\
\hline $2447783 \ldots \ldots$ & 7.88 & 11.35 & 0.54 & $\mathrm{~m} 57783 \mathrm{a}$ \\
\hline $2447788 \ldots$ & 8.44 & 11.05 & 0.36 & $\mathrm{~m} 57788 \mathrm{a}$ \\
\hline $2447816 \ldots \ldots$ & 9.33 & 11.28 & 1.39 & m57816a \\
\hline $2447831 \ldots \ldots$ & 8.96 & 10.52 & 0.92 & m57831a \\
\hline $2447837 \ldots \ldots$ & 8.95 & 10.59 & 0.73 & $\mathrm{~m} 57837 \mathrm{a}$ \\
\hline 2447846 .. & 9.36 & 10.62 & 0.56 & $\mathrm{~m} 57846 \mathrm{a}$ \\
\hline $2447852 \ldots \ldots$ & 9.82 & 10.63 & 0.41 & $\mathrm{~m} 57852 \mathrm{a}$ \\
\hline $2447868 \ldots \ldots$ & 11.75 & 10.61 & 1.04 & m57868a \\
\hline $2448020 \ldots$ & 12.14 & 13.43 & 2.05 & $\mathrm{~m} 58020 \mathrm{a}$ \\
\hline $2448037 \ldots \ldots$ & 12.45 & 12.65 & 1.44 & $\mathrm{~m} 58037 \mathrm{a}$ \\
\hline $2448044 \ldots \ldots$ & 12.47 & 12.63 & 1.11 & m58044a \\
\hline $2448061 \ldots \ldots$ & 13.71 & 12.31 & 1.39 & m58061a \\
\hline $2448068 \ldots$ & 13.81 & 12.13 & 1.83 & m58068a \\
\hline $2448077 \ldots \ldots$ & 13.93 & 11.66 & 1.91 & $\mathrm{~m} 58077 \mathrm{a}$ \\
\hline $2448090 \ldots \ldots$ & 13.91 & 12.04 & 2.11 & m58090a \\
\hline $2448112 \ldots \ldots$ & 14.47 & 12.43 & 2.81 & $\mathrm{~m} 58112 \mathrm{a}$ \\
\hline $2448128 \ldots \ldots$ & 13.57 & 13.20 & 2.09 & $\mathrm{~m} 58128 \mathrm{a}$ \\
\hline $2448143 \ldots \ldots$ & 13.35 & 12.80 & 2.07 & m58143a \\
\hline $2448148 \ldots \ldots$ & 13.63 & 13.19 & 2.24 & m58148a \\
\hline $2448149 .$. & 13.83 & 13.18 & 1.76 & m58149a \\
\hline $2448151 \ldots \ldots$ & 14.12 & 13.26 & 2.25 & $\mathrm{~m} 58151 \mathrm{a}$ \\
\hline $2448160 \ldots \ldots$ & 13.64 & 12.24 & 2.29 & $\mathrm{~m} 58160 \mathrm{a}$ \\
\hline $2448175 \ldots \ldots$ & 13.12 & 13.03 & 2.37 & $\mathrm{~m} 58175 \mathrm{a}$ \\
\hline $2448179 \ldots$ & 12.78 & 13.18 & 2.08 & m58179a \\
\hline $2448187 \ldots \ldots$ & 12.40 & 13.49 & 1.86 & $\mathrm{~m} 58187 \mathrm{a}$ \\
\hline $2448193 \ldots \ldots$ & 12.32 & 13.52 & 1.73 & m58193a \\
\hline $2448200 \ldots \ldots$ & 12.22 & 13.30 & 1.85 & $\mathrm{~m} 58200 \mathrm{a}$ \\
\hline $2448207 \ldots \ldots$ & 12.36 & 13.08 & 1.80 & $\mathrm{~m} 58207 \mathrm{a}$ \\
\hline $2448220 \ldots \ldots$ & 11.64 & 13.55 & 1.82 & $\mathrm{~m} 58220 \mathrm{a}$ \\
\hline $2448230 \ldots \ldots$ & 10.89 & 13.65 & 1.46 & $\mathrm{~m} 58230 \mathrm{a}$ \\
\hline $2448236 \ldots \ldots$ & 9.97 & 13.79 & 1.48 & m58236a \\
\hline $2448421 \ldots \ldots$ & 7.08 & 9.46 & 0.43 & m58421a \\
\hline $2448431 \ldots \ldots$ & 6.86 & 9.00 & 0.48 & m58431a \\
\hline $2448456 \ldots \ldots$ & 7.23 & 8.23 & 0.18 & m58456a \\
\hline $2448460 \ldots \ldots$ & 7.41 & 8.09 & 0.20 & $\mathrm{~m} 58460 \mathrm{a}$ \\
\hline $2448512 \ldots \ldots$ & 9.64 & 9.02 & 0.79 & $\mathrm{~m} 58512 \mathrm{a}$ \\
\hline $2448513 \ldots \ldots$ & 9.52 & 8.80 & 0.85 & $\mathrm{~m} 58513 \mathrm{a}$ \\
\hline $2448514 \ldots \ldots$ & 9.38 & 8.90 & 0.68 & $\mathrm{~m} 58514 \mathrm{a}$ \\
\hline $2448516 \ldots \ldots$ & 9.42 & 9.16 & 0.96 & m58516a \\
\hline $2448520 \ldots \ldots$ & 9.04 & 8.47 & 0.99 & $\mathrm{~m} 58520 \mathrm{a}$ \\
\hline $2448534 \ldots \ldots$ & 9.56 & 9.29 & 0.48 & $\mathrm{~m} 58534 \mathrm{a}$ \\
\hline $2448733 \ldots \ldots$ & 10.39 & 11.06 & 0.45 & $\mathrm{~m} 58733 \mathrm{a}$ \\
\hline $2448780 \ldots \ldots$ & 12.90 & 12.13 & 1.14 & $\mathrm{~m} 58780 \mathrm{a}$ \\
\hline $2448789 .$. & 12.82 & 12.90 & 1.43 & m58789a \\
\hline $2448796 \ldots \ldots$ & 12.69 & 12.51 & 1.05 & m58796a \\
\hline $2448810 \ldots \ldots$ & 13.68 & 12.50 & 1.03 & $\mathrm{~m} 58810 \mathrm{a}$ \\
\hline $2448817 \ldots \ldots$ & 14.62 & 12.82 & 1.51 & $\mathrm{~m} 58817 \mathrm{a}$ \\
\hline $2448825 \ldots \ldots$ & 14.61 & 12.63 & 1.72 & $\mathrm{~m} 58825 \mathrm{a}$ \\
\hline $2448839 \ldots \ldots$ & 14.38 & 12.81 & 1.39 & m58839a \\
\hline $2448848 \ldots \ldots$ & 14.61 & 13.64 & 1.59 & $\mathrm{~m} 58848 \mathrm{a}$ \\
\hline $2448862 \ldots \ldots$ & 14.26 & 13.47 & 1.84 & $\mathrm{~m} 58862 \mathrm{a}$ \\
\hline $2448869 \ldots \ldots$ & 14.39 & 13.36 & 1.83 & $\mathrm{~m} 58869 \mathrm{a}$ \\
\hline $2448876 \ldots \ldots$ & 14.76 & 13.42 & 1.74 & $\mathrm{~m} 58876 \mathrm{a}$ \\
\hline $2448883 \ldots \ldots$ & 14.65 & 13.66 & 2.00 & $\mathrm{~m} 58883 \mathrm{a}$ \\
\hline $2448889 \ldots \ldots$ & 14.38 & 13.68 & 1.94 & m58889a \\
\hline $2448898 \ldots \ldots$ & 14.42 & 13.76 & 1.94 & m58898a \\
\hline $2448904 \ldots \ldots$ & 14.27 & 14.12 & 2.01 & m58904a \\
\hline $2448911 \ldots \ldots$ & 14.47 & 14.38 & 2.07 & m58911a \\
\hline $2448918 \ldots \ldots$ & 13.79 & 13.64 & 1.65 & m58918a \\
\hline $2448929 \ldots \ldots$ & 14.08 & 13.61 & 1.91 & m58929a \\
\hline $2448954 \ldots \ldots$ & 14.07 & 14.66 & 1.74 & m58954a \\
\hline $2449079 \ldots \ldots$ & 12.51 & 13.84 & 2.33 & m59079a \\
\hline $2449099 \ldots \ldots$ & 11.58 & 13.72 & 2.23 & m59099a \\
\hline $2449107 \ldots \ldots$ & 10.97 & 13.90 & 2.23 & $\mathrm{~m} 59107 \mathrm{a}$ \\
\hline $2449114 \ldots \ldots$ & 10.29 & 14.29 & 1.73 & $\mathrm{~m} 59114 \mathrm{a}$ \\
\hline
\end{tabular}

TABLE 3-Continued

\begin{tabular}{|c|c|c|c|c|}
\hline $\begin{array}{c}\text { Julian Date } \\
\text { (1) }\end{array}$ & $F_{\lambda}(5110 \AA)^{\mathrm{a}}$ & $\begin{array}{c}F(\mathrm{H} \beta)^{\mathrm{b}} \\
(3)\end{array}$ & $\begin{array}{c}F(\mathrm{He} \mathrm{II})^{\mathrm{b}} \\
\text { (4) }\end{array}$ & $\begin{array}{c}\text { IRAF File } \\
\text { (5) }\end{array}$ \\
\hline 2449128 . & 10.33 & 13.61 & 1.84 & m59128a \\
\hline $2449135 \ldots \ldots$ & 10.29 & 13.94 & 1.85 & $\mathrm{~m} 59135 \mathrm{a}$ \\
\hline $2449142 \ldots \ldots$ & 10.14 & 13.70 & 1.99 & m59142a \\
\hline $2449149 \ldots \ldots$ & 10.04 & 13.77 & 2.12 & $\mathrm{~m} 59149 \mathrm{a}$ \\
\hline $2449156 \ldots \ldots$ & 9.80 & 13.16 & 1.90 & m59156a \\
\hline $2449163 \ldots \ldots$ & 9.25 & 13.36 & 1.62 & m59163a \\
\hline $2449169 \ldots \ldots$ & 8.92 & 13.30 & 1.31 & m59169a \\
\hline $2449176 \ldots \ldots$ & 8.67 & 12.96 & 1.23 & m59176a \\
\hline $2449183 \ldots \ldots$ & 8.60 & 12.72 & 1.04 & m59183a \\
\hline $2449190 \ldots \ldots$ & 9.21 & 12.14 & 1.11 & m59190a \\
\hline $2449197 \ldots \ldots$ & 9.60 & 11.88 & 1.47 & m59197a \\
\hline $2449205 \ldots \ldots$ & 9.77 & 11.82 & 1.83 & m59205a \\
\hline $2449211 \ldots \ldots$ & 9.73 & 12.16 & 1.78 & m59211a \\
\hline $2449233 \ldots \ldots$ & 9.53 & 12.18 & 1.72 & m59233a \\
\hline $2449240 \ldots \ldots$ & 9.17 & 12.00 & 1.47 & $\mathrm{~m} 59240 \mathrm{a}$ \\
\hline $2449245 \ldots \ldots$ & 9.05 & 12.04 & 1.44 & $\mathrm{~m} 59245 \mathrm{a}$ \\
\hline $2449246 \ldots \ldots$ & 8.96 & 12.16 & 1.36 & m59246a \\
\hline $2449253 \ldots \ldots$ & 9.09 & 12.02 & 1.29 & $\mathrm{~m} 59253 \mathrm{a}$ \\
\hline $2449260 \ldots \ldots$ & 9.10 & 12.11 & 1.07 & $\mathrm{~m} 59260 \mathrm{a}$ \\
\hline $2449268 \ldots \ldots$ & 9.54 & 11.68 & 1.46 & m59268a \\
\hline $2449275 \ldots \ldots$ & 9.44 & 11.67 & 1.50 & $\mathrm{~m} 59275 \mathrm{a}$ \\
\hline $2449282 \ldots \ldots$ & 9.66 & 12.50 & 1.70 & $\mathrm{~m} 59282 \mathrm{a}$ \\
\hline $2449296 \ldots \ldots$ & 9.42 & 11.81 & 1.46 & m59296a \\
\hline $2449309 \ldots \ldots$ & 9.89 & 11.76 & 1.48 & m59309a \\
\hline $2449316 \ldots \ldots$ & 9.76 & 11.83 & 1.92 & m59316a \\
\hline $2449323 \ldots \ldots$ & 9.59 & 11.78 & 1.78 & $\mathrm{~m} 59323 \mathrm{a}$ \\
\hline & B. & Reticon & & \\
\hline $2447415 \ldots \ldots$ & 10.94 & 13.42 & . & $\mathrm{m} 57415 \mathrm{~b}$ \\
\hline $2447420 \ldots \ldots$ & 10.76 & 13.18 & $\ldots$ & $\mathrm{m} 57420 \mathrm{~b}$ \\
\hline $2447421 \ldots \ldots$ & 10.52 & 13.39 & $\ldots$ & $\mathrm{m} 57421 \mathrm{~b}$ \\
\hline $2447442 \ldots \ldots$ & 11.26 & 12.77 & $\ldots$ & $\mathrm{m} 57442 \mathrm{~b}$ \\
\hline $2447446 \ldots \ldots$ & 10.72 & 12.82 & $\ldots$ & $\mathrm{m} 57446 \mathrm{~b}$ \\
\hline $2447472 \ldots \ldots$ & 10.98 & 13.40 & $\ldots$ & $\mathrm{m} 57472 \mathrm{~b}$ \\
\hline $2447478 \ldots \ldots$ & 10.85 & 13.23 & $\ldots$ & $\mathrm{m} 57478 \mathrm{~b}$ \\
\hline $2447497 \ldots \ldots$ & 11.02 & 13.51 & $\ldots$ & m57497b \\
\hline $2447498 \ldots \ldots$ & 11.46 & 14.35 & $\ldots$ & m57498b \\
\hline $2447500 \ldots \ldots$ & 10.96 & 13.57 & $\ldots$ & $\mathrm{m} 57500 \mathrm{~b}$ \\
\hline $2447501 \ldots \ldots$ & 11.12 & 15.13 & $\ldots$ & $\mathrm{m} 57501 \mathrm{~b}$ \\
\hline $2447717 \ldots \ldots$ & 11.50 & 15.78 & $\ldots$ & $\mathrm{m} 57717 \mathrm{~b}$ \\
\hline $2447777 \ldots \ldots$ & 8.06 & 13.79 & $\ldots$ & $\mathrm{m} 57777 \mathrm{~b}$ \\
\hline $2447798 \ldots \ldots$ & 9.31 & 14.46 & $\ldots$ & $\mathrm{m} 57798 \mathrm{~b}$ \\
\hline $2447799 \ldots \ldots$ & 9.23 & 13.81 & $\ldots$ & $\mathrm{m} 57799 \mathrm{~b}$ \\
\hline $2447800 \ldots \ldots$ & 9.23 & 13.57 & $\ldots$ & $\mathrm{m} 57800 \mathrm{~b}$ \\
\hline $2447805 \ldots \ldots$ & 9.30 & 13.19 & $\ldots$ & $\mathrm{m} 57805 \mathrm{~b}$ \\
\hline $2447823 \ldots \ldots$ & 9.49 & 13.09 & $\ldots$ & m57823b \\
\hline $2447824 \ldots \ldots$ & 10.01 & 12.09 & $\ldots$ & $\mathrm{m} 57824 \mathrm{~b}$ \\
\hline $2447826 \ldots \ldots$ & 9.68 & 13.47 & $\ldots$ & $\mathrm{m} 57826 \mathrm{~b}$ \\
\hline $2447829 \ldots \ldots$ & 9.04 & 13.34 & $\ldots$ & $\mathrm{m} 57829 \mathrm{~b}$ \\
\hline $2447831 \ldots \ldots$ & 8.71 & 12.62 & $\ldots$ & $\mathrm{m} 57831 \mathrm{~b}$ \\
\hline $2447832 \ldots \ldots$ & 8.91 & 12.90 & $\ldots$ & $\mathrm{m} 57832 \mathrm{~b}$ \\
\hline $2447833 \ldots \ldots$ & 8.83 & 13.28 & $\ldots$ & $\mathrm{m} 57833 \mathrm{~b}$ \\
\hline $2447834 \ldots \ldots$ & 8.63 & 12.48 & $\ldots$ & $\mathrm{m} 57834 \mathrm{~b}$ \\
\hline $2447835 \ldots \ldots$ & 8.49 & 12.19 & $\ldots$ & $\mathrm{m} 57835 \mathrm{~b}$ \\
\hline $2447859 \ldots \ldots$ & 11.17 & 12.81 & $\ldots$ & $\mathrm{m} 57859 \mathrm{~b}$ \\
\hline $2448059 \ldots \ldots$ & 12.92 & 14.93 & $\ldots$ & $\mathrm{m} 58059 \mathrm{~b}$ \\
\hline $2448060 \ldots \ldots$ & 12.59 & 13.58 & $\ldots$ & $\mathrm{m} 58060 \mathrm{~b}$ \\
\hline $2448061 \ldots \ldots$ & 12.31 & 14.55 & $\ldots$ & $\mathrm{m} 58061 \mathrm{~b}$ \\
\hline $2448064 \ldots \ldots$ & 13.42 & 13.79 & $\ldots$ & $\mathrm{m} 58064 \mathrm{~b}$ \\
\hline $2448065 \ldots \ldots$ & 13.23 & 15.10 & $\ldots$ & $\mathrm{m} 58065 \mathrm{~b}$ \\
\hline $2448151 \ldots \ldots$ & 13.71 & 14.58 & $\ldots$ & $\mathrm{m} 58151 \mathrm{~b}$ \\
\hline $2448162 \ldots \ldots$ & 13.72 & 14.65 & $\ldots$ & $\mathrm{m} 58162 \mathrm{~b}$ \\
\hline $2448179 \ldots \ldots$ & 13.54 & 16.54 & $\ldots$ & $\mathrm{m} 58179 \mathrm{~b}$ \\
\hline $2448187 \ldots \ldots$ & 12.99 & 16.75 & $\ldots$ & $\mathrm{m} 58187 \mathrm{~b}$ \\
\hline $2448188 \ldots \ldots$ & 12.08 & 16.28 & $\ldots$ & $\mathrm{m} 58188 \mathrm{~b}$ \\
\hline $2448189 \ldots \ldots$ & 12.30 & 14.72 & $\ldots$ & $\mathrm{m} 58189 \mathrm{~b}$ \\
\hline \multicolumn{5}{|c|}{ C. Palomar Double Spectrograph } \\
\hline 2448223 & 10.35 & 13.96 & 2.49 & $\mathrm{~m} 58223 \mathrm{c}$ \\
\hline
\end{tabular}


TABLE 3-Continued

\begin{tabular}{|c|c|c|c|c|}
\hline $\begin{array}{c}\text { Julian Date } \\
\text { (1) }\end{array}$ & $F_{\lambda}(5110 \AA)^{\mathrm{a}}$ & $\begin{array}{c}F(\mathrm{H} \beta)^{\mathrm{b}} \\
\quad(3)\end{array}$ & $\begin{array}{c}F(\mathrm{He} \mathrm{II})^{\mathrm{b}} \\
(4)\end{array}$ & $\begin{array}{l}\text { IRAF File } \\
\text { (5) }\end{array}$ \\
\hline \multicolumn{5}{|c|}{ D. Lick Shane CCD } \\
\hline $2448102 \ldots$. & 14.34 & 12.88 & 2.20 & $\mathrm{~m} 58102 \mathrm{~d}$ \\
\hline $2448161 \ldots$ & 14.53 & 13.33 & 2.60 & m58161d \\
\hline $2448184 \ldots$. & 14.24 & 15.02 & 1.73 & m58184d \\
\hline $2448206 \ldots$. & 13.78 & 14.96 & 1.80 & m58206d \\
\hline $2448472 \ldots$. & 7.96 & 9.14 & 0.41 & $\mathrm{~m} 58472 \mathrm{~d}$ \\
\hline $2448487 \ldots \ldots$ & 9.30 & 9.35 & 0.39 & $\mathrm{~m} 58487 \mathrm{~d}$ \\
\hline $2448798 \ldots$. & 13.15 & 13.51 & 1.33 & m58798d \\
\hline \multicolumn{5}{|c|}{ E. Steward CCD } \\
\hline $2447704 \ldots$. & 11.77 & 13.65 & 2.28 & $\mathrm{~m} 57704 \mathrm{ea}$ \\
\hline $2447767 \ldots$. & 9.22 & 12.74 & 1.15 & m57767ea \\
\hline $2447778 \ldots$. & 8.57 & 12.38 & 0.51 & m57778ea \\
\hline $2447779 \ldots$ & 8.68 & 11.58 & 0.73 & $\mathrm{~m} 57779 \mathrm{ea}$ \\
\hline \multicolumn{5}{|c|}{ F. Calar Alto CCD } \\
\hline $2447663 \ldots$. & 11.57 & 13.43 & 2.91 & $\mathrm{~m} 57663 \mathrm{fa}$ \\
\hline $2447664 \ldots$. & 11.60 & 14.02 & 3.11 & m57664fa \\
\hline $2447826 \ldots$. & 8.97 & 11.90 & 1.50 & $\mathrm{~m} 57826 \mathrm{f}$ \\
\hline $2448088 \ldots$. & 13.34 & 13.53 & 2.32 & $\mathrm{~m} 58088 \mathrm{f}$ \\
\hline
\end{tabular}

${ }^{\text {a }}$ In units of $10^{-15} \mathrm{ergs} \mathrm{s}^{-1} \mathrm{~cm}^{-2} \AA^{-1}$.

${ }^{\mathrm{b}}$ In units of $10^{-13} \mathrm{ergs} \mathrm{s}^{-1} \mathrm{~cm}^{-2}$.

uted to aperture effects. As in our other papers (Peterson et al. 1991, 1992, 1994; Dietrich et al. 1993; Korista et al. 1995), we determine an empirical correction for each of the data sets to bring them on to a common flux scale. We do this by arbitrarily adopting the largest data set (set "A") as a standard, and applying corrections to the other sets to bring measurements from the various sources into agreement. We first define a point-source correction factor $\varphi$ by the equation

$$
F(\mathrm{H} \beta)=\varphi F(\mathrm{H} \beta)_{\text {obs }},
$$

where the observed $\mathrm{H} \beta$ fluxes $F(\mathrm{H} \beta)_{\text {obs }}$ are as given in Table 3. This factor accounts for the fact that different apertures result in different amounts of light loss for the point-spread function (which describes the surface-brightness distribution of both the broad lines and the AGN continuum source) and the partially extended narrow-line region. We note, of course, that this correction factor is in principle a function of seeing (Peterson et al. 1995). We do not attempt to correct for seeing effects, and thus seeing effects probably contribute much of the total uncertainty in the measurements.

After applying the point-spread function correction $\varphi$, another correction needs to be applied to adjust for the

TABLE 4

Flux SCALe Factors

\begin{tabular}{|c|c|c|}
\hline $\begin{array}{l}\text { Data Set } \\
\text { (1) }\end{array}$ & $\begin{array}{c}\text { Point-Source Scale } \\
\text { Factor } \phi \\
\text { (2) }\end{array}$ & $\begin{array}{l}\text { Extended Source } \\
\text { Correction } G^{\mathrm{a}} \\
\text { (3) }\end{array}$ \\
\hline A. & 1.000 & 0.000 \\
\hline B ......... & $0.843 \pm 0.042$ & $-1.952 \pm 0.058$ \\
\hline & 0.970 & $-1 . \overline{590}$ \\
\hline D........ & $0.904 \pm 0.023$ & $-0.175 \pm 0.576$ \\
\hline E ........ & 0.980 & $0 . \overline{63} 6$ \\
\hline$F \ldots \ldots$ & $0.905 \pm 0.039$ & $-1.501 \pm 0.345$ \\
\hline
\end{tabular}

different amounts of starlight admitted by different apertures. We define an extended source correction $G$ as

$$
F_{\lambda}(5100 \AA)=\varphi F_{\lambda}(5100 \AA)_{\text {obs }}-G,
$$

where again $F_{\lambda}(5100 \AA)_{\text {obs }}$ is from Table 3 . The process of intercalibrating the various data sets is then carried out by comparing pairs of nearly simultaneous observations (i.e., to within 4 days) from different data sets to determine for each data set the values of the constants $\varphi$ and $G$ that are needed to adjust the emission-line and continuum fluxes to a common scale. Furthermore, the formal uncertainties in $\varphi$ and $G$ reflect the uncertainties in the individual data sets, so we can determine the nominal uncertainties for each data set if we assume that the errors add in quadrature. For the larger data sets, fractional uncertainties can be estimated independently by comparing closely spaced measurements. For the various data sets we find typical uncertainties of $\sim 2 \%-3 \%$ in the continuum and $\mathrm{H} \beta$ fluxes and $\sim 13 \%$ in He II $\lambda 4686$.

The intercalibration constants we use for each data set are given in Table 4, and these constants are used with equations (2) and (3) to adjust the measurements given in Table 3 to a common flux scale, which corresponds to measurements through the $5^{\prime \prime} .0 \times 7.5$ spectrograph entrance aperture used in set "A." The resultant values of the continuum flux $F_{\lambda}(5100 \AA)$ and the line fluxes $F(\mathrm{H} \beta)$ and $F(\mathrm{He}$ II 24686) are given in Table 5, which gives the complete light curve produced by computing the variance-weighted average of all the adjusted measurements obtained on a given Julian date. After completing the intercalibration, we can perform an additional check of our error estimates by examining the ratios of all pairs of closely spaced points in Table 5. In Table 5, there are 72 pairs of continuum measurements separated by 4 days or less, and we compute the ratio of all such pairs of measurements. The dispersion about the mean value of unity, divided by $2^{1 / 2}$, provides an estimate of the typical uncertainty in a single measurement. For the continuum, we find that the mean fractional error in a given measurement is 0.029 . The average fractional uncertainty, from the quoted estimates for these same 72 measurements in Table 5, is 0.025 , which implies that our error estimates are probably quite good. A similar analysis of the $\mathrm{H} \beta$ fluxes (again with 72 pairs separated by 4 days or less) yields an estimated uncertainty of 0.034 , compared to the mean quoted error of 0.028 , and for He II $\lambda 4686$ (with 23 pairs of closely spaced points), the uncertainty estimated from the dispersion in the ratios of closely spaced measurements is 0.13 , which is identical to the mean quoted error.

\section{VARIABILITY ANALYSIS}

\subsection{Characteristics of the Data Base}

Figure 2 shows the $5110 \AA$ continuum and $\mathrm{H} \beta$ and $\mathrm{He}$ II $\lambda 4686$ emission-line light curves from Table 5 . The continuum and $\mathrm{H} \beta$ measurements span a total of 1909 days, and the He II $\lambda 4686$ data cover 1671 days. Inspection of Figure 2 shows that the continuum and emission lines underwent large variations during the monitoring period and that in general these variations appear to be smooth and quite slow, at least in comparison to those seen in other well studied sources such as NGC 4151 (Clavel et al. 1990; Ulrich et al. 1991; Crenshaw et al. 1996), NGC 5548 (Peterson et al. 1994, and references therein), and NGC 3783 (Reichert et al. 1994; Stirpe et al. 1994). The variations 
TABLE 5

Optical ContinuUm and Emission-Line Light Curves

\begin{tabular}{|c|c|c|c|}
\hline $\begin{array}{c}\text { Julian Date } \\
\text { (1) }\end{array}$ & $F_{\lambda}(5110 \AA)^{\mathrm{a}}$ & $\begin{array}{c}F(\mathrm{H} \beta)^{\mathrm{b}} \\
\text { (3) }\end{array}$ & $\begin{array}{c}F(\mathrm{He} \mathrm{II})^{\mathrm{b}} \\
(4)\end{array}$ \\
\hline 2447415 . & $11.17 \pm 0.62$ & $11.31 \pm 0.45$ & $\cdots$ \\
\hline $2447420 \ldots \ldots$ & $11.03 \pm 0.61$ & $11.11 \pm 0.44$ & $\ldots$ \\
\hline 2447421 . & $10.82 \pm 0.60$ & $11.29 \pm 0.45$ & $\ldots$ \\
\hline 2447442 . & $11.44 \pm 0.63$ & $10.76 \pm 0.43$ & $\ldots$ \\
\hline $2447446 \ldots \ldots$ & $10.99 \pm 0.60$ & $10.81 \pm 0.43$ & $\ldots$ \\
\hline $2447472 \ldots \ldots$ & $11.21 \pm 0.62$ & $11.30 \pm 0.45$ & $\ldots$ \\
\hline 2447478 . & $11.10 \pm 0.61$ & $11.15 \pm 0.45$ & $\ldots$ \\
\hline 2447497 . & $11.24 \pm 0.62$ & $11.39 \pm 0.46$ & $\ldots$ \\
\hline 2447498 . & $11.61 \pm 0.64$ & $12.10 \pm 0.48$ & $\ldots$ \\
\hline 2447500 . & $11.19 \pm 0.62$ & $11.44 \pm 0.46$ & $\ldots$ \\
\hline $2447501 \ldots$ & $11.32 \pm 0.62$ & $12.76 \pm 0.51$ & $\ldots$ \\
\hline 2447653 . & $11.59 \pm 0.23$ & $12.63 \pm 0.32$ & $2.16 \pm 0.28$ \\
\hline $2447657 \ldots \ldots$ & $11.86 \pm 0.24$ & $12.61 \pm 0.31$ & $1.80 \pm 0.23$ \\
\hline $2447663 \ldots \ldots$ & $11.97 \pm 0.30$ & $12.15 \pm 0.30$ & $2.63 \pm 0.34$ \\
\hline 2447664 . & $12.00 \pm 0.30$ & $12.69 \pm 0.32$ & $2.82 \pm 0.37$ \\
\hline 2447678 . & $11.23 \pm 0.22$ & $12.34 \pm 0.31$ & $2.32 \pm 0.30$ \\
\hline 2447704 . & $10.90 \pm 0.33$ & $13.37 \pm 0.33$ & $2.24 \pm 0.29$ \\
\hline 2447717 . & $11.65 \pm 0.64$ & $13.30 \pm 0.53$ & $\ldots$ \\
\hline 2447767 . & $8.40 \pm 0.25$ & $12.48 \pm 0.31$ & $1.13 \pm 0.15$ \\
\hline $2447777 \ldots \ldots$ & $8.75 \pm 0.48$ & $11.62 \pm 0.47$ & $\ldots$ \\
\hline $2447778 \ldots \ldots$ & $7.77 \pm 0.23$ & $12.14 \pm 0.30$ & $0.50 \pm 0.06$ \\
\hline 2447779 . & $7.87 \pm 0.24$ & $11.35 \pm 0.28$ & $0.71 \pm 0.09$ \\
\hline 2447783 . & $7.88 \pm 0.16$ & $11.35 \pm 0.28$ & $0.54 \pm 0.07$ \\
\hline $2447788 \ldots \ldots$ & $8.44 \pm 0.17$ & $11.05 \pm 0.28$ & $0.36 \pm 0.05$ \\
\hline 2447798 & $9.80 \pm 0.54$ & $12.19 \pm 0.49$ & $\ldots$ \\
\hline 2447799. & $9.73 \pm 0.54$ & $11.65 \pm 0.47$ & $\ldots$ \\
\hline $2447800 \ldots \ldots$ & $9.73 \pm 0.54$ & $11.44 \pm 0.46$ & $\ldots$ \\
\hline $2447805 \ldots \ldots$ & $9.79 \pm 0.54$ & $11.12 \pm 0.44$ & $\ldots$ \\
\hline 2447816 . & $9.33 \pm 0.19$ & $11.28 \pm 0.28$ & $1.39 \pm 0.18$ \\
\hline 2447823 . & $9.95 \pm 0.55$ & $11.03 \pm 0.44$ & $\ldots$ \\
\hline $2447824 \ldots \ldots$ & $10.39 \pm 0.57$ & $10.19 \pm 0.41$ & $\ldots$ \\
\hline 2447826 . & $9.70 \pm 0.22$ & $10.92 \pm 0.23$ & $1.36 \pm 0.18$ \\
\hline 2447829 . & $9.57 \pm 0.53$ & $11.25 \pm 0.45$ & $\ldots$ \\
\hline $2447831 \ldots \ldots$ & $9.00 \pm 0.17$ & $10.55 \pm 0.22$ & $0.92 \pm 0.12$ \\
\hline $2447832 \ldots \ldots$ & $9.47 \pm 0.52$ & $10.88 \pm 0.44$ & $\ldots$ \\
\hline 2447833 . & $9.40 \pm 0.52$ & $11.19 \pm 0.45$ & $\ldots$ \\
\hline 2447834 . & $9.23 \pm 0.51$ & $10.52 \pm 0.42$ & $\ldots$ \\
\hline $2447835 \ldots \ldots$ & $9.11 \pm 0.50$ & $10.27 \pm 0.41$ & \\
\hline $2447837 \ldots \ldots$ & $8.95 \pm 0.18$ & $10.59 \pm 0.26$ & $0.73 \pm 0.09$ \\
\hline 2447846 . & $9.36 \pm 0.19$ & $10.62 \pm 0.27$ & $0.56 \pm 0.07$ \\
\hline $2447852 \ldots \ldots$ & $9.82 \pm 0.20$ & $10.63 \pm 0.27$ & $0.41 \pm 0.05$ \\
\hline $2447859 \ldots \ldots$ & $11.37 \pm 0.62$ & $10.80 \pm 0.43$ & $\ldots$ \\
\hline 2447868 . & $11.75 \pm 0.23$ & $10.61 \pm 0.26$ & $1.04 \pm 0.14$ \\
\hline 2448020 . & $12.14 \pm 0.24$ & $13.43 \pm 0.34$ & $2.05 \pm 0.27$ \\
\hline $2448037 \ldots \ldots$ & $12.45 \pm 0.25$ & $12.65 \pm 0.32$ & $1.44 \pm 0.19$ \\
\hline $2448044 \ldots \ldots$ & $12.47 \pm 0.25$ & $12.63 \pm 0.32$ & $1.11 \pm 0.14$ \\
\hline 2448059 . & $12.84 \pm 0.71$ & $12.59 \pm 0.50$ & $\ldots$ \\
\hline $2448060 \ldots \ldots$ & $12.56 \pm 0.69$ & $11.45 \pm 0.46$ & $\ldots$ \\
\hline $2448061 \ldots \ldots$ & $13.52 \pm 0.25$ & $12.29 \pm 0.26$ & $1.39 \pm 0.18$ \\
\hline 2448064 . & $13.26 \pm 0.73$ & $11.63 \pm 0.47$ & $\ldots$ \\
\hline $2448065 \ldots \ldots$ & $13.10 \pm 0.72$ & $12.73 \pm 0.51$ & $\ldots$ \\
\hline $2448068 \ldots \ldots$ & $13.81 \pm 0.28$ & $12.13 \pm 0.30$ & $1.83 \pm 0.24$ \\
\hline $2448077 \ldots \ldots$ & $13.93 \pm 0.28$ & $11.66 \pm 0.29$ & $1.91 \pm 0.25$ \\
\hline 2448088 . & $13.57 \pm 0.34$ & $12.24 \pm 0.31$ & $2.10 \pm 0.27$ \\
\hline 2448090 . & $13.91 \pm 0.28$ & $12.04 \pm 0.30$ & $2.11 \pm 0.28$ \\
\hline $2448102 \ldots \ldots$ & $13.14 \pm 0.39$ & $11.64 \pm 0.29$ & $1.99 \pm 0.26$ \\
\hline $2448112 \ldots \ldots$ & $14.47 \pm 0.29$ & $12.43 \pm 0.31$ & $2.81 \pm 0.37$ \\
\hline 2448128 . & $13.57 \pm 0.27$ & $13.20 \pm 0.33$ & $2.09 \pm 0.27$ \\
\hline $2448143 \ldots \ldots$ & $13.35 \pm 0.27$ & $12.80 \pm 0.32$ & $2.07 \pm 0.27$ \\
\hline $2448148 \ldots \ldots$ & $13.63 \pm 0.27$ & $13.19 \pm 0.33$ & $2.24 \pm 0.29$ \\
\hline 2448149 . & $13.83 \pm 0.28$ & $13.18 \pm 0.33$ & $1.76 \pm 0.23$ \\
\hline $2448151 \ldots \ldots$ & $14.04 \pm 0.26$ & $12.95 \pm 0.27$ & $2.25 \pm 0.29$ \\
\hline $2448160 \ldots \ldots$ & $13.64 \pm 0.27$ & $12.24 \pm 0.31$ & $2.29 \pm 0.30$ \\
\hline $2448161 \ldots \ldots$ & $13.31 \pm 0.40$ & $12.05 \pm 0.30$ & $2.35 \pm 0.31$ \\
\hline $2448162 \ldots \ldots$ & $13.52 \pm 0.74$ & $12.35 \pm 0.49$ & $\ldots$ \\
\hline $2448175 \ldots \ldots$ & $13.12 \pm 0.26$ & $13.03 \pm 0.33$ & $2.37 \pm 0.31$ \\
\hline $2448179 \ldots \ldots$ & $12.85 \pm 0.24$ & $13.38 \pm 0.28$ & $2.08 \pm 0.27$ \\
\hline $2448184 \ldots \ldots$ & $13.05 \pm 0.39$ & $13.58 \pm 0.34$ & $1.57 \pm 0.20$ \\
\hline $2448187 \ldots \ldots$ & $12.45 \pm 0.23$ & $13.66 \pm 0.29$ & $1.86 \pm 0.24$ \\
\hline $2448188 \ldots \ldots$ & $12.14 \pm 0.67$ & $13.72 \pm 0.55$ & $\ldots$ \\
\hline $2448189 \ldots \ldots$ & $12.32 \pm 0.68$ & $12.41 \pm 0.50$ & $\ldots$ \\
\hline $2448193 \ldots \ldots$ & $12.32 \pm 0.25$ & $13.52 \pm 0.34$ & $1.73 \pm 0.22$ \\
\hline
\end{tabular}

TABLE 5-Continued

\begin{tabular}{|c|c|c|c|}
\hline $\begin{array}{c}\text { Julian Date } \\
\text { (1) }\end{array}$ & $F_{\lambda}(5110 \AA)^{\mathrm{a}}$ & $\begin{array}{c}F(\mathrm{H} \beta)^{\mathrm{b}} \\
(3)\end{array}$ & $\begin{array}{c}F(\mathrm{He} \text { II })^{b} \\
\text { (4) }\end{array}$ \\
\hline 2448200 . & $12.22 \pm 0.24$ & $13.30 \pm 0.33$ & $1.85 \pm 0.24$ \\
\hline 2448206 . & $12.63 \pm 0.38$ & $13.52 \pm 0.34$ & $1.63 \pm 0.21$ \\
\hline 2448207 . & $12.36 \pm 0.25$ & $13.08 \pm 0.33$ & $1.80 \pm 0.23$ \\
\hline 2448220 . & $11.64 \pm 0.23$ & $13.55 \pm 0.34$ & $1.82 \pm 0.24$ \\
\hline 2448223 . & $11.63 \pm 0.35$ & $13.54 \pm 0.34$ & $2.41 \pm 0.31$ \\
\hline 2448230. & $10.89 \pm 0.22$ & $13.65 \pm 0.34$ & $1.46 \pm 0.19$ \\
\hline 2448236 . & $9.97 \pm 0.20$ & $13.79 \pm 0.34$ & $1.48 \pm 0.19$ \\
\hline 2448421 . & $7.08 \pm 0.14$ & $9.46 \pm 0.24$ & $0.43 \pm 0.06$ \\
\hline 2448431 . & $6.86 \pm 0.14$ & $9.00 \pm 0.22$ & $0.48 \pm 0.06$ \\
\hline $2448456 \ldots \ldots$ & $7.23 \pm 0.14$ & $8.23 \pm 0.21$ & $0.18 \pm 0.02$ \\
\hline 2448460 . & $7.41 \pm 0.15$ & $8.09 \pm 0.20$ & $0.20 \pm 0.03$ \\
\hline 2448472 . & $7.37 \pm 0.22$ & $8.27 \pm 0.21$ & $0.38 \pm 0.05$ \\
\hline 2448487 . & $8.59 \pm 0.26$ & $8.45 \pm 0.21$ & $0.36 \pm 0.05$ \\
\hline 2448512 . & $9.64 \pm 0.19$ & $9.02 \pm 0.22$ & $0.79 \pm 0.10$ \\
\hline 2448513 . & $9.52 \pm 0.19$ & $8.80 \pm 0.22$ & $0.85 \pm 0.11$ \\
\hline 2448514 . & $9.38 \pm 0.19$ & $8.90 \pm 0.22$ & $0.68 \pm 0.09$ \\
\hline $2448516 \ldots$ & $9.42 \pm 0.19$ & $9.16 \pm 0.23$ & $0.96 \pm 0.12$ \\
\hline 2448520 . & $9.04 \pm 0.18$ & $8.47 \pm 0.21$ & $0.99 \pm 0.13$ \\
\hline 2448534 . & $9.56 \pm 0.19$ & $9.29 \pm 0.23$ & $0.48 \pm 0.06$ \\
\hline 2448733 . & $10.39 \pm 0.21$ & $11.06 \pm 0.28$ & $0.45 \pm 0.06$ \\
\hline 2448780 . & $12.90 \pm 0.26$ & $12.13 \pm 0.30$ & $1.14 \pm 0.15$ \\
\hline 2448789 . & $12.82 \pm 0.26$ & $12.90 \pm 0.32$ & $1.43 \pm 0.19$ \\
\hline $2448796 \ldots \ldots$ & $12.69 \pm 0.25$ & $12.51 \pm 0.31$ & $1.05 \pm 0.14$ \\
\hline $2448798 \ldots$ & $12.07 \pm 0.36$ & $12.21 \pm 0.31$ & $1.20 \pm 0.16$ \\
\hline 2448810 . & $13.68 \pm 0.27$ & $12.50 \pm 0.31$ & $1.03 \pm 0.13$ \\
\hline $2448817 \ldots \ldots$ & $14.62 \pm 0.29$ & $12.82 \pm 0.32$ & $1.51 \pm 0.20$ \\
\hline $2448825 \ldots \ldots$ & $14.61 \pm 0.29$ & $12.63 \pm 0.32$ & $1.72 \pm 0.22$ \\
\hline 2448839 & $14.38 \pm 0.29$ & $12.81 \pm 0.32$ & $1.39 \pm 0.18$ \\
\hline $2448848 \ldots \ldots$ & $14.61 \pm 0.29$ & $13.64 \pm 0.34$ & $1.59 \pm 0.21$ \\
\hline $2448862 \ldots \ldots$ & $14.26 \pm 0.28$ & $13.47 \pm 0.34$ & $1.84 \pm 0.24$ \\
\hline 2448869 . & $14.39 \pm 0.29$ & $13.36 \pm 0.33$ & $1.83 \pm 0.24$ \\
\hline 2448876 . & $14.76 \pm 0.29$ & $13.42 \pm 0.34$ & $1.74 \pm 0.23$ \\
\hline $2448883 \ldots \ldots$ & $14.65 \pm 0.29$ & $13.66 \pm 0.34$ & $2.00 \pm 0.26$ \\
\hline $2448889 \ldots \ldots$ & $14.38 \pm 0.29$ & $13.68 \pm 0.34$ & $1.94 \pm 0.25$ \\
\hline 2448898 . & $14.42 \pm 0.29$ & $13.76 \pm 0.34$ & $1.94 \pm 0.25$ \\
\hline 2448904 . & $14.27 \pm 0.28$ & $14.12 \pm 0.35$ & $2.01 \pm 0.26$ \\
\hline 2448911 . & $14.47 \pm 0.29$ & $14.38 \pm 0.36$ & $2.07 \pm 0.27$ \\
\hline $2448918 \ldots \ldots$ & $13.79 \pm 0.28$ & $13.64 \pm 0.34$ & $1.65 \pm 0.22$ \\
\hline 2448929. & $14.08 \pm 0.28$ & $13.61 \pm 0.34$ & $1.91 \pm 0.25$ \\
\hline $2448954 \ldots \ldots$ & $14.07 \pm 0.28$ & $14.66 \pm 0.37$ & $1.74 \pm 0.23$ \\
\hline $2449079 \ldots \ldots$ & $12.51 \pm 0.25$ & $13.84 \pm 0.35$ & $2.33 \pm 0.30$ \\
\hline 2449099 . & $11.58 \pm 0.23$ & $13.72 \pm 0.34$ & $2.23 \pm 0.29$ \\
\hline $2449107 \ldots \ldots$ & $10.97 \pm 0.22$ & $13.90 \pm 0.35$ & $2.23 \pm 0.29$ \\
\hline $2449114 \ldots \ldots$ & $10.29 \pm 0.21$ & $14.29 \pm 0.36$ & $1.73 \pm 0.22$ \\
\hline $2449128 \ldots \ldots$ & $10.33 \pm 0.21$ & $13.61 \pm 0.34$ & $1.84 \pm 0.24$ \\
\hline $2449135 \ldots \ldots$ & $10.19 \pm 0.20$ & $13.94 \pm 0.35$ & $1.85 \pm 0.24$ \\
\hline $2449142 \ldots \ldots$ & $10.14 \pm 0.20$ & $13.70 \pm 0.34$ & $1.99 \pm 0.26$ \\
\hline $2449149 \ldots \ldots$ & $10.04 \pm 0.20$ & $13.77 \pm 0.34$ & $2.12 \pm 0.28$ \\
\hline 2449156. & $9.80 \pm 0.20$ & $13.16 \pm 0.33$ & $1.90 \pm 0.25$ \\
\hline $2449163 \ldots \ldots$ & $9.25 \pm 0.19$ & $13.36 \pm 0.33$ & $1.62 \pm 0.21$ \\
\hline $2449169 \ldots \ldots$ & $8.92 \pm 0.18$ & $13.30 \pm 0.33$ & $1.31 \pm 0.17$ \\
\hline $2449176 \ldots \ldots$ & $8.67 \pm 0.17$ & $12.96 \pm 0.32$ & $1.23 \pm 0.16$ \\
\hline $2449183 \ldots \ldots$ & $8.60 \pm 0.17$ & $12.72 \pm 0.32$ & $1.04 \pm 0.14$ \\
\hline $2449190 \ldots \ldots$ & $9.21 \pm 0.18$ & $12.14 \pm 0.30$ & $1.11 \pm 0.14$ \\
\hline $2449197 \ldots \ldots$ & $9.60 \pm 0.19$ & $11.89 \pm 0.30$ & $1.47 \pm 0.19$ \\
\hline $2449205 \ldots$ & $9.77 \pm 0.19$ & $11.82 \pm 0.29$ & $1.83 \pm 0.24$ \\
\hline $2449211 \ldots \ldots$ & $9.74 \pm 0.19$ & $12.16 \pm 0.30$ & $1.78 \pm 0.23$ \\
\hline $2449233 \ldots \ldots$ & $9.53 \pm 0.19$ & $12.18 \pm 0.31$ & $1.72 \pm 0.22$ \\
\hline $2449240 \ldots \ldots$ & $9.17 \pm 0.18$ & $12.00 \pm 0.30$ & $1.47 \pm 0.19$ \\
\hline 2449245. & $9.05 \pm 0.18$ & $12.04 \pm 0.30$ & $1.44 \pm 0.19$ \\
\hline $2449246 \ldots \ldots$ & $8.96 \pm 0.18$ & $12.16 \pm 0.30$ & $1.36 \pm 0.18$ \\
\hline $2449253 \ldots \ldots$ & $9.09 \pm 0.18$ & $12.02 \pm 0.30$ & $1.29 \pm 0.17$ \\
\hline $2449260 \ldots$ & $9.10 \pm 0.18$ & $12.11 \pm 0.30$ & $1.07 \pm 0.14$ \\
\hline $2449268 \ldots \ldots$ & $9.54 \pm 0.19$ & $11.68 \pm 0.29$ & $1.46 \pm 0.19$ \\
\hline $2449275 \ldots \ldots$ & $9.44 \pm 0.19$ & $11.67 \pm 0.29$ & $1.50 \pm 0.19$ \\
\hline $2449282 \ldots \ldots$ & $9.66 \pm 0.19$ & $12.50 \pm 0.31$ & $1.70 \pm 0.22$ \\
\hline $2449296 \ldots$ & $9.41 \pm 0.19$ & $11.81 \pm 0.29$ & $1.46 \pm 0.19$ \\
\hline $2449309 \ldots \ldots$ & $9.89 \pm 0.20$ & $11.76 \pm 0.29$ & $1.48 \pm 0.19$ \\
\hline $2449316 \ldots \ldots$ & $9.76 \pm 0.19$ & $11.83 \pm 0.30$ & $1.92 \pm 0.25$ \\
\hline $2449323 \ldots \ldots$ & $9.59 \pm 0.19$ & $11.78 \pm 0.29$ & $1.78 \pm 0.23$ \\
\hline
\end{tabular}

\footnotetext{
${ }^{a}$ In units of $10^{-15} \mathrm{ergs} \mathrm{s}^{-1} \mathrm{~cm}^{-2} \AA^{-1}$.

b In units of $10^{-13} \mathrm{ergs} \mathrm{s}^{-1} \mathrm{~cm}^{-2}$.
} 


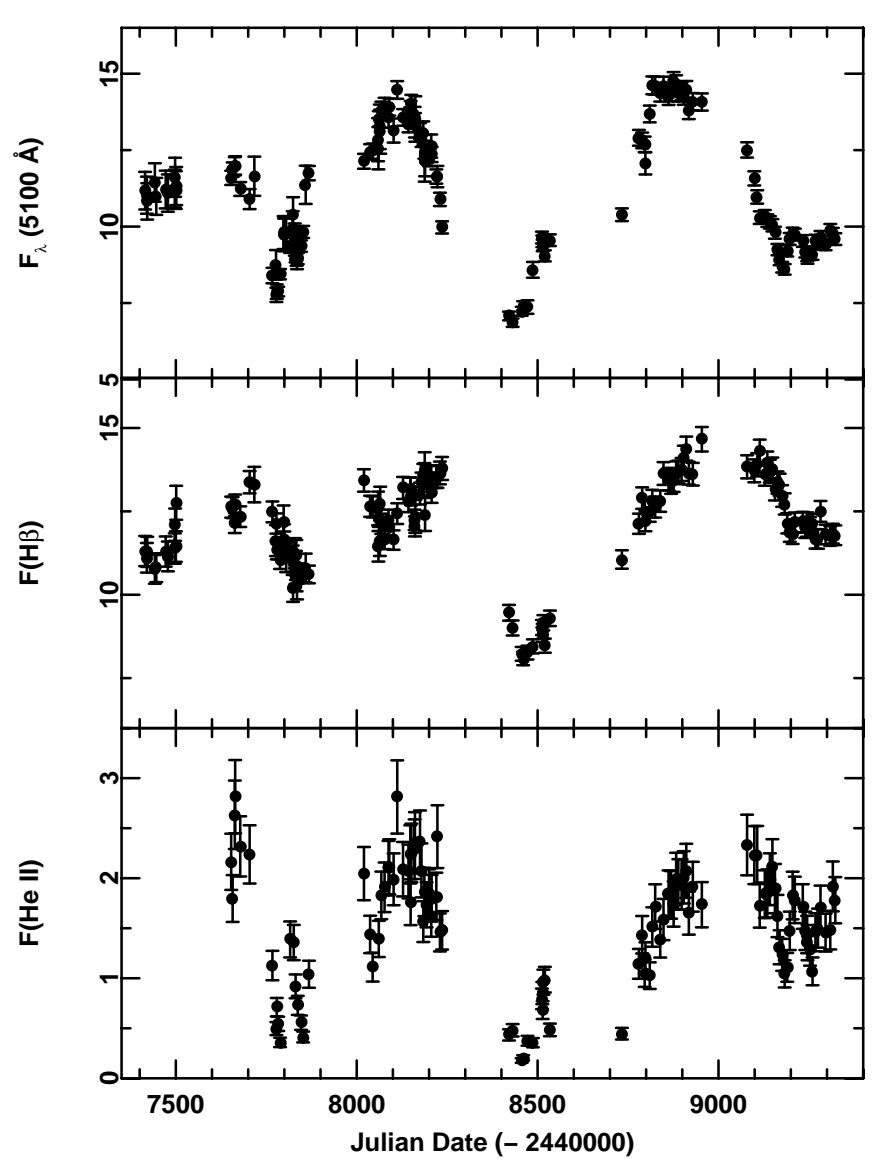

FIG. 2.-The continuum fluxes at $5110 \AA$ (top panel), $\mathrm{H} \beta$ emission-line fluxes (middle panel), and He II $\lambda 4686$ fluxes (bottom panel) for Mrk 509, as given in Table 5, from 1989 September to 1993 December. Fluxes are in the

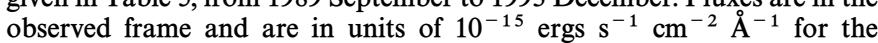
continuum and $10^{-13} \mathrm{ergs} \mathrm{s}^{-1} \mathrm{~cm}^{-2}$ for the lines.

appear to be well resolved with our median sampling of 7 days. The relatively large interseason gaps are due to the southern declination $\left(\delta \approx-11^{\circ}\right)$ of Mrk 509; all of the telescopes that were employed in this study are at northern hemisphere observatories. These gaps introduce some uncertainty into our conclusions, since in no single observing season did we see the related inflection points in the continuum and $\mathrm{H} \beta$ light curves that are required for an unambiguous measurement of the time delay. This bright source would be an excellent candidate for a long-term southern hemisphere monitoring program.

The sampling characteristics of this experiment and some simple parameters that describe the amplitude of variation are given in Table 6 . The fractional variation $F_{\text {var }}$ is the ratio of the rms fluctuation to the mean flux and is corrected for the effect of measurement errors (see Clavel et al. 1991). The parameter $R_{\max }$ is the ratio of maximum to minimum flux. Neither of these parameters has been adjusted for the effects of nonvarying components, such as the stellar continuum or the narrow components of the emission lines.

\subsection{Time Series Analysis}

A characteristic response time for the broad emission lines can be determined by cross-correlation of the continuum and emission-line light curves. We employ both of the commonly used methods for cross-correlation of unevenly sampled AGN light curves, the interpolation method of Gaskell \& Sparke (1986) and the discrete correlation function (DCF) method of Edelson \& Krolik (1988). The specific versions of the algorithms we use are described by White $\&$ Peterson (1994).

The results of the cross-correlation analysis are summarized in Table 7. The correlation functions computed from the entire data sets are shown in Figure 3. The upper panel of Figure 3 shows the interpolation CCF and the DCF obtained by cross-correlation of the optical continuum and $\mathrm{H} \beta$ light curves. The middle panel shows the optical continuum/He II $\lambda 4686$ cross-correlation. The lower panel shows both the corresponding continuum autocorrelation function (ACF) and the sampling window autocorrelation function; the latter is produced by averaging the ACFs obtained by repeatedly sampling a white noise spectrum in exactly the same pattern as the real observations and then computing the ACF by the interpolation method. The interpolation process automatically introduces a correlation extending from zero lag to a value that characterizes the typical sampling interval, and thus the sampling window ACF provides a good indication of how much of the width of the ACF is due to interpolation rather than to real correlation between continuum points at different times (see Gaskell \& Peterson 1987). The ACF (FWHM = 191 days) is very much broader than the sampling window ACF $(\mathrm{FWHM}=7$ days), which indicates that the crosscorrelation results are not dominated by interpolation artifacts. In Table 7, the parameter $r_{\max }$ is the peak value of the interpolation CCF, which occurs at a time delay $\tau_{\text {peak }}$, and $\tau_{\text {cent }}$ refers to the centroid of the CCF, which is computed by including only those points within $0.5 r_{\text {max }}$.

In order to assess how robust our calibration and crosscorrelation procedures are, we also carried out the time series analysis based on only the single largest data set (set "A"), and these results are also given in Table 7 . Only the He II $\lambda 4686$ centroid changes significantly. That this is due primarily to the omission of the continuum points from the first year (i.e., prior to JD 2,447,653) is demonstrated by again using the full data base, but excluding the more-or-

TABLE 6

VARIABILITY PARAMETERS AND SAMPling CharaCteristics

\begin{tabular}{|c|c|c|c|c|c|c|c|}
\hline \multirow[b]{2}{*}{$\begin{array}{l}\text { FEATURE } \\
\text { (1) }\end{array}$} & \multirow[b]{2}{*}{$\begin{array}{c}\text { NUMBER OF } \\
\text { EPOCHS } \\
(2)\end{array}$} & \multirow[b]{2}{*}{$\begin{array}{c}\text { Total Span } \\
\text { (Days) } \\
\text { (3) }\end{array}$} & \multicolumn{2}{|c|}{$\begin{array}{c}\text { SAMPLING INTERVAL } \\
\text { (Days) }\end{array}$} & \multirow[b]{2}{*}{$\begin{array}{l}\text { MEAN FLUX } \\
(6)\end{array}$} & \multirow[b]{2}{*}{$\begin{array}{c}F_{\mathrm{var}} \\
(7)\end{array}$} & \multirow[b]{2}{*}{$R_{\max }$} \\
\hline & & & $\begin{array}{l}\text { Average } \\
\text { (4) }\end{array}$ & $\begin{array}{l}\text { Median } \\
(5)\end{array}$ & & & \\
\hline$F_{\lambda}(5110 \AA) \ldots . .$. & 142 & 1909 & 13.5 & 7 & 11.17 & 0.182 & 2.15 \\
\hline $\mathrm{H} \beta \lambda 4861 \ldots \ldots \ldots$ & 142 & 1909 & 13.5 & 7 & 12.06 & 0.119 & 1.81 \\
\hline He II $\lambda 4686 \ldots . .$. & 110 & 1671 & 15.3 & 7 & 1.53 & 0.382 & 15.8 \\
\hline
\end{tabular}

a Units as in Table 5. 
TABLE 7

Cross-Correlation Results: Optical Continutu versus Emission Lines

\begin{tabular}{|c|c|c|c|c|c|c|}
\hline \multirow[b]{2}{*}{$\begin{array}{l}\text { Data SET } \\
\text { (1) }\end{array}$} & \multicolumn{3}{|c|}{$\mathrm{H} \beta \lambda 4861$} & \multicolumn{3}{|c|}{ He II $\lambda 4686$} \\
\hline & $\begin{array}{c}\tau_{\text {peak }} \\
\text { (days) } \\
(2)\end{array}$ & $\begin{array}{c}\tau_{\text {cent }} \\
\text { (days) } \\
(3)\end{array}$ & $\begin{array}{l}r_{\max } \\
\text { (4) }\end{array}$ & $\begin{array}{c}\tau_{\text {peak }} \\
\text { (days) } \\
(5)\end{array}$ & $\begin{array}{c}\tau_{\text {cent }} \\
\text { (days) } \\
(6)\end{array}$ & $\begin{array}{c}r_{\max } \\
(7)\end{array}$ \\
\hline All data & 86 & 80.2 & 0.878 & 64 & 61.8 & 0.725 \\
\hline Set A only & 87 & 87.4 & 0.889 & 58 & 87.7 & 0.738 \\
\hline JD $2447653-2449323$ only ...... & 86 & 81.0 & 0.882 & 64 & 81.3 & 0.753 \\
\hline
\end{tabular}

less isolated continuum points from the first year (see Table 7); the range in time considered is more important than either the total number of data points or the effects of the intercalibration process.

The cross-correlation lags are well defined quantities, although the results shown in Table 7 make it clear that ambiguities can arise depending the computational details. There is no generally agreed upon way to establish formal uncertainties for lags measured from unevenly sampled data drawn from irregular light curves. Monte Carlo simulations are often employed, but the results are nevertheless very sensitive to the specific model assumptions that are made.

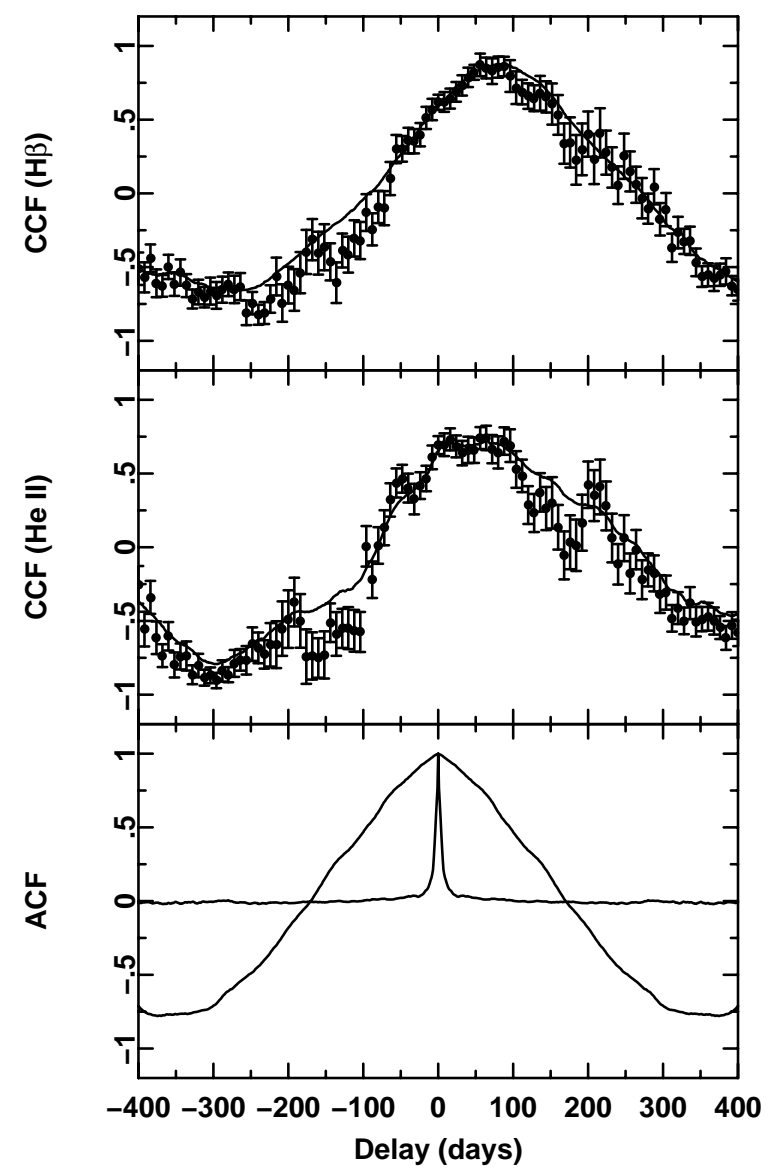

FIG. 3.-The top panel shows the optical continuum-H $\beta$ crosscorrelation function computed from the data in Table 5 and Fig. 2. The optical continuum-He II $\lambda 4686$ cross-correlation function is shown in the middle panel. The solid lines show the interpolation cross-correlation function (Gaskell \& Sparke 1986), and the filled circles with error bars show the DCF values (Edelson \& Krolik 1988), in both cases computed as described by White \& Peterson (1994). The bin width for the DCF is 8 days. The optical continuum autocorrelation function and the sampling window autocorrelation function appear in the lower panel.
Gaskell \& Peterson (1987) suggest an analytic formula for estimating the uncertainties in cross-correlation lags. Comparison of estimates based on this formula with results of Monte Carlo simulations suggests that the GaskellPeterson formula slightly overestimates the errors when the light curves are well sampled (as they appear to be in this case), but grossly underestimate the errors when the sampling is poor (Maoz \& Netzer 1989; White \& Peterson 1994). For the CCFs computed here, the Gaskell-Peterson formula yields estimates of the uncertainties in the lags of $\sim 7$ days, which is about the same as the median sampling interval. We emphasize that the cross-correlation lag gives merely a scale length for the BLR and that when good sampling is achieved the uncertainties in the BLR geometry become far more important than the formal uncertainties in the cross-correlation lag measurements.

\section{DISCUSSION}

A striking result of this program is that the emission-line lags are so large and the continuum variations so slow that it would not have been possible to measure the lag accurately based on data from only a single observing season. Indeed, we were somewhat confused by the data from the first 2 years of data because derivatives of the continuum and $\mathrm{H} \beta$ light curves seemed to have different signs much of the time, and it was only with several years of data that the true pattern began to emerge.

The lags measured for $\mathrm{H} \beta$ and $\mathrm{He}$ II $\lambda 4686$ in Mrk 509 are a factor of 3-4 larger than lags that have been reliably measured for these lines in other AGNs. Only in the case of the very luminous Seyfert 1 galaxy Fairall 9 (Clavel, Wamsteker, \& Glass 1989) have longer lags been reliably measured for any lines, and the formal measurement errors are uncomfortably large in that case (see Shields, Ferland, \& Peterson 1995). We illustrate this in Figure 4, which shows the relationship between the size of the Balmer-line emitting region (usually based on $\mathrm{H} \beta$ lags, but in some cases on $\mathrm{H} \alpha$ ) and the optical continuum specific luminosity for well observed AGNs. The data were drawn from published sources, in order of increasing optical luminosity, from Maoz et al. (1991) for NGC 4151, Salamanca et al. (1994) and Winge et al. (1995) for NGC 3227, Dietrich et al.(1994) for NGC 4593, Winge et al. (1996) for IC 4329A, Stirpe et al. (1994) for NGC 3783, Peterson et al. (1994) for NGC 5548, Wanders et al. (1993) for NGC 3516, Peterson et al. (1993) for Mrk 590, Kassebaum et al. (1996) for Mrk 335, Maoz et al. (1990) for Mrk 279, and this paper for Mrk 509. Figure 4 is plotted so that a diagonal line corresponds to the prediction of equation (1). On the basis of the data shown in Figure 4, the prediction of equation (1) is neither verified nor disproved. The fact that a large lag is measured for the most luminous source is of course reassuring, but the range 


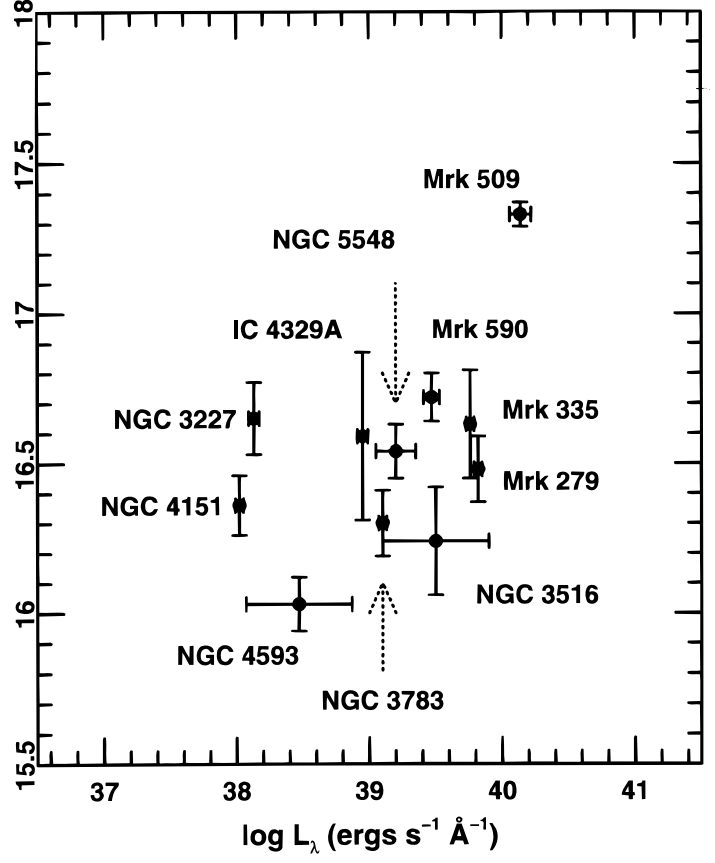

FIG. 4.-The radius-luminosity relationship for the broad-line regions in Seyfert galaxies. The BLR radius is taken to be $r=c \tau_{\text {cent }}$, where $\tau_{\text {cent }}$ is the centroid of the optical continuum/Balmer-line (usually $\mathrm{H} \beta$ ) crosscorrelation function. The optical specific luminosity (for $\mathrm{H}_{0}=100 \mathrm{~km} \mathrm{~s}^{-1}$ $\mathrm{Mpc}^{-1}$ ) generally refers to the AGN component only, i.e., with the starlight contribution subtracted whenever possible.

Blandford, R. D., \& McKee, C. F. 1982, ApJ, 255, 419

Clavel, J., et al. 1990, MNRAS, 246, 668 1991, ApJ, 366, 64

Clavel, J., Wamsteker, W., \& Glass, I. S. 1989, ApJ, 337, 236

Crenshaw, D. M., et al. 1996, ApJ, 470, in press

Dietrich, M., et al. 1993, ApJ, 408, 416 .1994, A\&A, 284, 33

Edelson, R. A., \& Krolik, J. H. 1988, ApJ, 333, 646

Erkens, U., et al. 1995, A\&A, 296, 90

Gaskell, C. M., \& Peterson, B. M., 1987, ApJS, 65, 1

Gaskell, C. M., \& Sparke, L. S. 1986, ApJ, 305, 175

Kassebaum, T. M., Peterson, B. M., Wanders, I., Pogge, R. W., Bertram, R. \& Wagner, R. M. 1996, ApJ, submitted

Korista, K. T., et al. 1995, ApJS, 97, 285

Maoz, D. 1994, in Reverberation Mapping of the Broad-Line Region in Active Galactic Nuclei, ed. P. M. Gondhalekar, K. Horne, \& B. M. Peterson (San Francisco: ASP), 95

Maoz, D., et al. 1990, ApJ, 351,75

$$
1991 \text {, ApJ, 367, } 493
$$

Maoz, D., \& Netzer, H.. 1989, MNRAS, 236, 21

Maoz, D., Smith, P. S., Jannuzi, B. T., Kaspi, S., \& Netzer, H. 1994, ApJ, 421,34

Peterson, B. M. 1993, PASP, 105, 247 of luminosity that has been explored at this time is still not sufficient to adequately test the relationship. There are several sources of widely different luminosities which have very similar Balmer-line lags in the range of two to three weeks (corresponding to BLR scale lengths of $\sim 3-5 \times 10^{16}$ $\mathrm{cm}$ ), and these introduce much scatter into the observed relationship. This is plausibly attributable to these AGNs having slightly different spectral shapes and emission-line strengths, in which case the $r \propto L^{1 / 2}$ prediction is so approximate that a larger range of luminosity or more detailed photoionization modeling of individual sources will be required for a meaningful test.

We are very grateful to the Directors and Telescope Allocation Committees of our various observatories for their support of this project. Individual investigators have benefited from support from a number of agencies, including the following: the National Science Foundation: AST 91-17086 and AST 94-20080 (Ohio State University), AST 89-57063 and AST 90-03829 (University of California, Berkeley), and the NSF Graduate Fellowship program (T. M.); NASA: NAG 5-1630 (P. S. S.), NAS 8-30751 and NAS 5-30934 (Center for Astrophysics), and Long-Term Space Astrophysics grant NAGW-3315 (B. M. P.); and BMFT grant Verbundforschung Astronomie DFG Ko857/13-1 (Universitäts-Sternwarte Göttingen).

\section{REFERENCES}

Peterson, B. M. 1994, in Reverberation Mapping of the Broad-Line Region in Active Galactic Nuclei, ed. P. M. Gondhalekar, K. Horne, \& B. M. Peterson (San Francisco: ASP), 1

Peterson, B. M., et al. 1991, ApJ, 368, 119

1992, ApJ, 392, 470

Peterson, B. M., Ali, B., Horne, K., Bertram, R. Lame, N. J., Pogge, R. W., \& Wagner, R. M. 1993, ApJ, 402, 469

Peterson, B. M., et al. 1994, ApJ, 425, 622

Peterson, B. M., Pogge, R. W., Wanders, I., Smith, S. M., \& Romanishin, W. 1995, PASP, 107,579

Reichert, G. A., et al. 1994, ApJ, 425, 582

Salamanca, I., et al. 1994, A\&A, 282, 742

Schmidt, M., \& Green, R. F. 1983, ApJ, 269, 352

Shields, J. C., Ferland, G. J., \& Peterson, B. M. 1995, ApJ, 441, 507

Stirpe, G. M., et al. 1994, ApJ, 425, 609

Ulrich, M.-H., et al. 1991, ApJ, 382, 483

van Groningen, E., \& Wanders, I. 1992, PASP, 104, 700

Wanders, I., et al. 1993, A\&A, 269, 39

White, R. J., \& Peterson, B. M. 1994, PASP, 106, 879

Winge, C., Peterson, B. M., Horne, K., Pogge, R. W., Pastoriza, M. G., \& Storchi-Bergmann, T. 1995, ApJ, 445, 680

Winge, C., Peterson, B. M., Pastoriza, M. G., \& Storchi-Bergmann, T. 1996, ApJ, 470, in press 